\title{
Recent Advances in Alternaria Phytotoxins: A Review of Their Occurrence, Structure, Bioactivity, and Biosynthesis
}

\author{
He Wang ${ }^{1}$, Yanjing Guo ${ }^{1}$, Zhi Luo ${ }^{1}$, Liwen Gao ${ }^{1}$, Rui Li ${ }^{2}$, Yaxin Zhang ${ }^{1}$, Hazem M. Kalaji ${ }^{3,4}$, , Sheng Qiang ${ }^{1}$ \\ and Shiguo Chen $1, * \mathbb{E}$
}

Citation: Wang, H.; Guo, Y.; Luo, Z.; Gao, L.; Li, R.; Zhang, Y.; Kalaji, H.M.; Qiang, S.; Chen, S. Recent Advances in Alternaria Phytotoxins: A Review of Their Occurrence, Structure, Bioactivity, and Biosynthesis. J. Fungi 2022, 8, 168. https://doi.org/ $10.3390 /$ jof 8020168

Academic Editor: Baojun Xu

Received: 31 December 2021

Accepted: 7 February 2022

Published: 9 February 2022

Publisher's Note: MDPI stays neutral with regard to jurisdictional claims in published maps and institutional affiliations.

Copyright: (C) 2022 by the authors. Licensee MDPI, Basel, Switzerland. This article is an open access article distributed under the terms and conditions of the Creative Commons Attribution (CC BY) license (https:// creativecommons.org/licenses/by/ $4.0 /)$.
1 Weed Research Laboratory, College of Life Science, Nanjing Agricultural University, Nanjing 210095, China; 2018216001@njau.edu.cn (H.W.); 2021216003@stu.njau.edu.cn (Y.G.); 2020116003@stu.njau.edu.cn (Z.L.); gaoliwen0905@163.com (L.G.); 2019116003@njau.edu.cn (Y.Z.); wrl@njau.edu.cn (S.Q.)

2 Agricultural and Animal Husbandry Ecology and Resource Protection Center, Ordos Agriculture and Animal Husbandry Bureau, Ordos 017010, China; lirui01@163.com

3 Department of Plant Physiology, Institute of Biology, Warsaw University of Life Sciences SGGW, 159 Nowoursynowska 159, 02-776 Warsaw, Poland; hazem@kalaji.pl

4 Institute of Technology and Life Sciences-National Research Institute, Falenty, Al. Hrabska 3, 05-090 Raszyn, Poland

* Correspondence: chenshg@njau.edu.cn; Tel.: +86-25-84395117

\begin{abstract}
Alternaria is a ubiquitous fungal genus in many ecosystems, consisting of species and strains that can be saprophytic, endophytic, or pathogenic to plants or animals, including humans. Alternaria species can produce a variety of secondary metabolites (SMs), especially low molecular weight toxins. Based on the characteristics of host plant susceptibility or resistance to the toxin, Alternaria phytotoxins are classified into host-selective toxins (HSTs) and non-host-selective toxins (NHSTs). These Alternaria toxins exhibit a variety of biological activities such as phytotoxic, cytotoxic, and antimicrobial properties. Generally, HSTs are toxic to host plants and can cause severe economic losses. Some NHSTs such as alternariol, altenariol methyl-ether, and altertoxins also show high cytotoxic and mutagenic activities in the exposed human or other vertebrate species. Thus, Alternaria toxins are meaningful for drug and pesticide development. For example, AAL-toxin, maculosin, tentoxin, and tenuazonic acid have potential to be developed as bioherbicides due to their excellent herbicidal activity. Like altersolanol A, bostrycin, and brefeldin A, they exhibit anticancer activity, and ATX V shows high activity to inhibit the HIV-1 virus. This review focuses on the classification, chemical structure, occurrence, bioactivity, and biosynthesis of the major Alternaria phytotoxins, including 30 HSTs and 50 NHSTs discovered to date.
\end{abstract}

Keywords: Alternaria toxins; HSTs; NHSTs; biological activities; biosynthesis

\section{Introduction}

The fungal genus Alternaria is a widespread and successful group growing in diverse environments worldwide, ranging from saprophytes to pathogens and even endophytes. The genus Alternaria was identified in the year 1816 [1]. Currently, about 300 species have been described based on phylogenetic and morphological studies, which have been further divided into 26 sections [2-4]. As an outstanding group of fungal pathogens, Alternaria species can either cause diseases in a wide range of economically important crops [1], resulting in significant economic losses, or affect human and animal health, such as through upper respiratory tract infections and asthma [4,5].

To date, over 70 toxins with different chemical structures and behaviors are known to be produced by Alternaria species [6]. These toxins often exhibit a variety of bioactivities, such as phytotoxic, cytotoxic, and antimicrobial properties, etc. Generally, Alternaria phytotoxins are divided into host-selective toxins (HSTs) and non-host-selective toxins (NHSTs) based on the susceptibility or resistance of the host. HSTs are toxic only to host 
plants. In contrast, NHSTs can affect many plants, regardless of whether they are a host or non-host of the pathogen producing them [7]. Most HSTs have been considered as pathogenicity factors required for fungi to invade tissues and cause disease. On the other hand, NHSTs may contribute to the development of symptoms and the proliferation of plant pathogens $[8,9]$.

Here, we review the toxins produced by Alternaria spp. and summarize the classification, occurrence, mode of action, biological activity, biosynthesis, and development value of each toxin. The phytotoxins presented in the paper will be termed "toxins", and those toxic to animals will be termed "mycotoxins".

\section{Host-Selective Toxins}

In this section, we reviewed 30 HSTs of Alternaria and summarised the related pathotypes, diseases caused, chemical properties, targets in plant organelles, and biosynthetic pathways of these toxins (Table 1). Based on their chemical structures, the HSTs of Alternaria can be classified into seven classes: (1) epoxy-decatrienoic acid (AK-toxins, AF-toxins, and ACT-toxins); (2) sphinganine analogue (AAL-toxins); (3) pyranones (ACR-toxins); (4) cyclic peptide (AM-toxins, destruxin B, and HC-toxin); (5) tetrapeptide (AS-I toxin); (6) diketopiperazine (maculosin); and (7) ribosomal peptide (ABR-toxin). In fact, the classes (4), (5), and (6) also fall into the larger family of non-ribosomal peptides.

Table 1. Host-selective toxins produced by Alternaria species.

\begin{tabular}{|c|c|c|c|}
\hline Toxins & Alternaria Species & Host Range & References \\
\hline $\begin{array}{l}\text { AK-toxins } \\
\text { (AK-toxin I, II) }\end{array}$ & $\begin{array}{l}\text { A. alternata f. sp. kikuchana } \\
\text { (Japanese pear pathotype) }\end{array}$ & Japanese pear & [9-11] \\
\hline $\begin{array}{c}\text { AF-toxins } \\
\text { (AF-toxin I, II, III) }\end{array}$ & $\begin{array}{l}\text { A. alternata f. sp. Fragariae } \\
\text { (Strawberry pathotype) }\end{array}$ & Strawberry & [12] \\
\hline $\begin{array}{l}\text { ACT-toxins } \\
\text { (ACT-toxin I, II) }\end{array}$ & $\begin{array}{l}\text { A. alternata } \mathrm{f} \text {. sp. citri tangerine } \\
\text { (Tangerine pathotype) }\end{array}$ & Tangerine & [13-15] \\
\hline $\begin{array}{c}\text { AAL-toxins } \\
\left(\mathrm{TA}_{1}, \mathrm{TA}_{2}, \mathrm{~TB}_{1}, \mathrm{~TB}_{2}, \mathrm{TC}_{1}, \mathrm{TC}_{2}, \mathrm{TD}_{1}, \mathrm{TD}_{2}, \mathrm{TE}_{1}, \mathrm{TE}_{2}\right)\end{array}$ & $\begin{array}{l}\text { A. alternata f. sp. lycopersici } \\
\text { (Tomato pathotype) }\end{array}$ & Tomato & {$[16,17]$} \\
\hline $\begin{array}{l}\text { ACR-toxins } \\
\text { (ACR-toxin I, II, III, IV, IV') }\end{array}$ & $\begin{array}{l}\text { A. alternata f. sp. citri jambhiri } \\
\text { (Rough lemon pathotype) }\end{array}$ & Rough lemon & {$[18,19]$} \\
\hline $\begin{array}{l}\text { AM-toxins } \\
\text { (AM-toxin I, II, III) }\end{array}$ & $\begin{array}{l}\text { A. alternata f. sp. mali } \\
\text { (Apple pathotype) }\end{array}$ & Apple & {$[20,21]$} \\
\hline Destruxin B & A. brassicae & Brassica spp. & {$[22,23]$} \\
\hline HC-toxin & $\begin{array}{l}\text { C. carbonum and } A \text {. jesenskae } \\
\text { A. alternata }\end{array}$ & Maize & [24-26] \\
\hline Maculosin & $\begin{array}{l}\text { (Spotted knapweed } \\
\text { pathotype) }\end{array}$ & knapweed & {$[27,28]$} \\
\hline AS-I toxin & $\begin{array}{c}\text { A. alternata } \\
\text { (Sunflower Pathotype) }\end{array}$ & Sunflower & [29] \\
\hline ABR-toxin & A. brassicae & Brassica spp. & [23] \\
\hline
\end{tabular}

\subsection{AK-Toxins, AF-Toxins, and ACT-Toxins}

AK-toxins produced by the Japanese pear pathotype of A. alternata f. sp. Kikuchana were first described in Japanese pear black spot disease [9-11]. The same researchers identified the chemical structure, absolute configuration, and biological activity of these toxins [10]. AK-toxins are the esters of 9,10-epoxy-8-hydroxy-9-methyl-decatrienoic acid (EDA), which are the derivative of phenylalanine and hydroxyldecartienoic acid. AKtoxins consist of two types, AK-toxins I and II. Both are also mixtures of three geometric isomers, namely type-a $(2 E, 4 E, 6 Z)$, type-b $(2 E, 4 Z, 6 E)$, and type-c $(2 E, 4 E, 6 E)$. For each compound, the main geometry is type-b (Figure 1a) [30]. Both toxins showed toxicity only in susceptible pear cultivars, and AK-toxin I was more abundant and showed higher biological activity [31,32]. In Nijisseike, a susceptible Japanese pear cultivar, the concentration that caused venous necrosis was $5 \mathrm{nM}$ of AK-toxin I or $100 \mathrm{nM}$ of AK-toxin II. However, at 
$0.1 \mathrm{mM}$ of AK-toxins I and II, there was no effect on the leaves of a resistant cultivar such as Chojuro [31].

Alternaria black spot disease of strawberry was first reported in 1977 and the causal pathogen was identified as A. alternata strawberry pathotype (A. alternata f. sp. fragariae) [12] The pathogen produces three key molecules, AF-toxins I, II, and III (Figure 1b). AF-toxins I and II were isolated in 1979 and AF-toxin III was isolated in 1984. The chemical structures of these three toxins were first determined in 1986 [33]. The three AF-toxins have the same EDA structures, which are very similar to the AK-toxins. The conformation of the EDA parts of the AF-toxin is type-a $(2 E, 4 E, 6 \mathrm{Z})$. Of these three toxins, AF-toxin I is toxic to strawberries and pears, AF-toxin II shows toxicity to pears only, and AF-toxin III shows high toxicity to strawberries but low toxicity to pears [34].

a<smiles>[R]C(c1ccccc1)[C@H](NC(C)=O)C(=O)O[C@H](/C=C/C=C/C=C/[C@@H](C)O)C1(C)CO1</smiles>

AK-toxins

I: $\mathrm{R}=\mathrm{CH}_{3}$

II: $\mathrm{R}=\mathrm{H}$ b<smiles>[R]OC(C(=O)O[C@H](/C=C/C=C/C=C/C(=O)O)[C@H]1CO1)C(C)CC</smiles>

II: $\mathrm{R}=\mathrm{H}$

III: $\mathrm{R}=\mathrm{COCH}(\mathrm{OH}) \mathrm{CH}\left(\mathrm{CH}_{3}\right)_{2}$

C<smiles></smiles>

ACT-toxins

I: $\mathrm{R}=\mathrm{OH}$

II: $\mathrm{R}=\mathrm{H}$

Figure 1. Chemical structures of AK-toxins (a), AF-toxins (b), and ACT-toxins (c).

Alternaria brown spot disease of the emperor mandarin was first reported in Australia in 1903, and the pathogen was identified as the mandarin pathotype of A. alternata f. sp. citri tangerine in 1966 [13]. This pathotype is highly toxic to mandarins, tangerines, grapefruit, and hybrids of grapefruit and tangerine, as well as mandarin and sweet orange [14]. The crucial pathogenicity depends on the action of ACT-toxins (Figure 1c). It can cause brown to black spots on young leaves, twigs, and fruits of tangerines. ACT-toxins can also be transmitted through the veins and cause more severe lesions [15]. ACT-toxins at a concentration of $2 \times 10^{-8} \mathrm{M}$ can cause necrotic lesions on citrus leaves with rapid electrolyte loss from the host cells. The ACT-toxins consist of three components, EDA, valine, and polyketide. ACT-toxins have two types that differ only in the R group. The conformation of the EDA component of ACT-toxins is the type B form $(2 E, 4 Z, 6 E)$. ACT-toxins are more abundant and toxic to citrus [35].

The target of action of AK-, AF-, and ACT-toxins is the plasma membrane of susceptible cells [34-37]. They cause a sudden, and markedly increased, $\mathrm{K}^{+}$loss from the plasma membrane after a few minutes of toxin treatment, resulting in membrane invagination, vesiculation, fragmentation, and depolarization, which causes a decrease in the membrane potential gradient $[37,38]$. Within 1-3 h after toxin treatment, Golgi vesicles fuse with the damaged plasma membrane [37]. No damage was observed in intracellular organelles, except for the plasma membrane of host cells. Of these three toxins, AK-toxins and AFtoxins irreversibly depolarized the plasma membrane of susceptible genotypes and could 
directly affect the plasma membrane $\mathrm{H}^{+}$-ATPase [39-42]. In the case of AK-toxins, the configuration at C-8 and C-9 was critical for phytotoxicity [43].

Recently, some genes were discovered to play important biological and pathological roles in the pathotype of A. alternata. Two NADPH (nicotinamide adenine dinucleotide phosphate) oxidase genes (NoxA and NoxB) were identified, and NoxB was found to be essential for the aggressiveness and basal pathogenicity of $A$. alternata [44]. The gene PEX6, encoding a protein required for the import of matrix proteins into peroxisomes, has been characterized in A. alternata. It plays a role in ROS (reactive oxygen species)-induced resistance and fungal pathogenicity in the mandarin pathotype of A. alternata [45].

AK-toxins, AF-toxins, and ACT-toxins have a common component, EDA, in their structures $[10,11,35]$. In a previous study, based on the $\left[2-{ }^{13} \mathrm{C}\right]$-sodium acetate feeding study of the Japanese pear pathotype of $A$. alternata and ${ }^{13} \mathrm{C}$ NMR spectrum analysis, it was demonstrated that AK-toxins are biosynthesized from acetic acid via EDA [46]. In another study, ${ }^{3} \mathrm{H}$-labeled EDA was added to a growing liquid culture of the strain of the Japanese pear pathotype and was efficiently converted to AK-toxins. These results confirmed that EDA is an intermediate for toxin pathways [15].

The gene cluster involved in HST biosynthesis of $A$. alternata pathogens was first isolated from the Japanese pear pathotype, including AKT1, AKT2, AKT3, AKT4, AKTR, and AKTS1 $[47,48]$. Recently, another gene, $A K T 7$, encoding a cytochrome P450 monooxygenase was found to have the function of limiting the production of AK-toxin [7]. The biosynthetic genes of AF-toxins and ACT-toxins were identified by genomic cosmid libraries of the two pathotypes screened with the $A K T$ gene probes [38]. For the biosynthetic genes of AF-toxins (AFT-genes), eleven AFT-genes and five transposon-like sequences (TLS-S1 to TLS-S5) were isolated [49]. Among them, AFT1, AFT3, and AFTR show strong similarity to AKT1, AKT3, and $A K T R$, respectively [49]. The biosynthetic pathway of ACT-toxins was also found to be regulated by several genes, including ACTT1, ACTT2, ACTT3, ACTT5, ACTT6, ACTTS2, and ACTTS3 [9,50-52], and ACTT1 and ACTT2 were considered to be the highly homologous genes of $A K T 1$ and $A K T 2$, respectively, in the Japanese pear pathotype [52]. AKT1, AKT2, and $A K T 3$ were identified as involved in the biosynthesis of EDA, a common component of AK-, AF-, and ACT-toxins in the Japanese pear pathotype, as well as their orthologs in the strawberry and tangerine pathotypes [53]. Recently, a transcriptional regulator ACTR was identified to contribute to the biosynthesis of ACT-toxins via the mediator gene ACTS4 in A. alternata [54]. These three genes were clustered on small chromosomes of less than $2.0 \mathrm{Mb}$ in three pathotypic strains. They are not required for growth but confer an advantage in colonizing certain ecological niches [49,51,55-57].

\subsection{AAL-Toxins}

Alternaria stem canker disease is a serious disease of tomato (Lycopersicon esculentum Mill.). The disease was first described in 1975 [58]. It caused dark brown to black cankers on the stems of some tomato cultivars by a pathogenic strain, A. alternata $\mathrm{f}$. sp. Lycopersici $[16,17]$. AAL-toxins were the main causative agent of the disease produced by the above pathogen. The first AAL-toxin was isolated in 1981 and its chemical structures, TA and TB, analogues of sphingosine and sphinganine, respectively, were determined [59-61]. To date, five types of AAL-toxin-related molecules, TA and TB, TC, TD, and TE, have been identified. Each of these fractions consisted of a mixture of two structural isomers (Figure 2). TA and TB showed toxicity to detached tomato leaves at $10 \mathrm{ng} \cdot \mathrm{mL}^{-1}$. The toxicity of TD and TE is over 100 times lower than that of the form TA. The activity of TC was lower than that of TA, but higher than that of TD and TE [62]. Unlike other HSTs produced by A. alternata, the AAL-toxins can attack many other weeds, crops, and at least 25 species of solanaceous plants in addition to the susceptible tomato host $[63,64]$. On the other hand, some crops (e.g., maize, wheat, and resistant tomato varieties) are tolerant to AAL-toxins. Thus, AAL-toxins have been considered as very low-dose herbicides against a variety of broadleaf weeds such as datura, pricklesida, and black nightshade $[63,65]$. In addition, AAL-toxins are also toxic to cultured mammalian cells. The $\mathrm{IC}_{50}$ value for the most sensitive 
hepatoma line, H4TG, was $10 \mu \mathrm{g} \cdot \mathrm{mL}^{-1}$ [66]. Such fact did limit the development of AALtoxins as herbicides compared with some common herbicides, such as glyphosate, that are less toxic to mammals with the $\mathrm{LD}_{50}$ ranging from 800 to $>5000 \mathrm{mg} \cdot \mathrm{kg}^{-1}$ body weight for different animal species [67]. Recently, some AAL-toxin analogues were synthesized and one of them showed significant phytotoxicity and low mammalian toxicity, giving them potential for being developed as safe and effective natural herbicides $[68,69]$.<smiles>[R5]NCC(O)C[C@@H]([Y9])C([R5])CCCCCC(C)CC([R20])[C@H](O[Z20])C(C)CC</smiles>

\section{AAL-toxins}

$\mathrm{TA}_{1}: \mathrm{R}_{1}=\mathrm{H}, \mathrm{R}_{2}=\mathrm{CO}-\mathrm{CH}_{2}-\mathrm{CH}(\mathrm{COOH})-\mathrm{CH}_{2}-\mathrm{COOH}, \mathrm{R}_{3}=\mathrm{OH}, \mathrm{R}_{4}=\mathrm{OH}, \mathrm{R}_{5}=\mathrm{H}$

$\mathrm{TA}_{2}: \mathrm{R}_{1}=\mathrm{CO}-\mathrm{CH}_{2}-\mathrm{CH}(\mathrm{COOH})-\mathrm{CH}_{2}-\mathrm{COOH}, \mathrm{R}_{2}=\mathrm{H}, \mathrm{R}_{3}=\mathrm{OH}, \mathrm{R}_{4}=\mathrm{OH}, \mathrm{R}_{5}=\mathrm{H}$

$\mathrm{TB}_{1}: \mathrm{R}_{1}=\mathrm{H}, \mathrm{R}_{2}=\mathrm{CO}-\mathrm{CH}_{2} \mathrm{CH}(\mathrm{COOH})-\mathrm{CH}_{2}-\mathrm{COOH}, \mathrm{R}_{3}=\mathrm{H}, \mathrm{R}_{4}=\mathrm{OH}, \mathrm{R}_{5}=\mathrm{H}$

$\mathrm{TB}_{2}: \mathrm{R}_{1}=\mathrm{CO}-\mathrm{CH}_{2}-\mathrm{CH}(\mathrm{COOH})-\mathrm{CH}_{2}-\mathrm{COOH}, \mathrm{R}_{2}=\mathrm{H}, \mathrm{R}_{3}=\mathrm{H}, \mathrm{R}_{4}=\mathrm{OH}, \mathrm{R}_{5}=\mathrm{H}$

$\mathrm{TC}_{1}: \mathrm{R}_{1}=\mathrm{H}, \mathrm{R}_{2}=\mathrm{CO}-\mathrm{CH}_{2}-\mathrm{CH}(\mathrm{COOH})-\mathrm{CH}_{2}-\mathrm{COOH}, \mathrm{R}_{3}=\mathrm{H}, \mathrm{R}_{4}=\mathrm{H}, \mathrm{R}_{5}=\mathrm{H}$

$\mathrm{TC}_{2}: \mathrm{R}_{1}=\mathrm{CO}-\mathrm{CH}_{2}-\mathrm{CH}(\mathrm{COOH})-\mathrm{CH}_{2}-\mathrm{COOH}, \mathrm{R}_{2}=\mathrm{H}, \mathrm{R}_{3}=\mathrm{H}, \mathrm{R}_{4}=\mathrm{H}, \mathrm{R}_{5}=\mathrm{H}$

$\mathrm{TD}_{1}: \mathrm{R}_{1}=\mathrm{H}, \mathrm{R}_{2}=\mathrm{CO}-\mathrm{CH}_{2}-\mathrm{CH}(\mathrm{COOH})-\mathrm{CH}_{2}-\mathrm{COOH}, \mathrm{R}_{3}=\mathrm{H}, \mathrm{R}_{4}=\mathrm{OH}, \mathrm{R}_{5}=\mathrm{COCH}_{3}$

$\mathrm{TD}_{2}: \mathrm{R}_{1}=\mathrm{CO}-\mathrm{CH}_{2}-\mathrm{CH}(\mathrm{COOH})-\mathrm{CH}_{2}-\mathrm{COOH}, \mathrm{R}_{2}=\mathrm{H}, \mathrm{R}_{3}=\mathrm{H}, \mathrm{R}_{4}=\mathrm{OH}, \mathrm{R}_{5}=\mathrm{COCH}_{3}$

$T_{1}: R_{1}=\mathrm{H}, \mathrm{R}_{2}=\mathrm{CO}-\mathrm{CH}_{2}-\mathrm{CH}(\mathrm{COOH})-\mathrm{CH}_{2}-\mathrm{COOH}, \mathrm{R}_{3}=\mathrm{H}, \mathrm{R}_{4}=\mathrm{H}, \mathrm{R}_{5}=\mathrm{COCH}_{3}$

$\mathrm{TE}_{2}: \mathrm{R}_{1}=\mathrm{CO}-\mathrm{CH}_{2}-\mathrm{CH}(\mathrm{COOH})-\mathrm{CH}_{2}-\mathrm{COOH}, \mathrm{R}_{2}=\mathrm{H}, \mathrm{R}_{3}=\mathrm{H}, \mathrm{R}_{4}=\mathrm{H}, \mathrm{R}_{5}=\mathrm{COCH}_{3}$

Figure 2. Chemical structures of AAL-toxins.

When susceptible tomato leaves were treated with AAL-toxins, the accumulation of two amines, ethanolamine (EA) and phosphoethanolamine (PEA), occurred. This implies that AAL-toxins could interfere with amine metabolism [70]. When the ${ }^{14} \mathrm{C}$ label of EA was fed to susceptible leaf disks treated with AAL-toxins, there was a strong inhibition of the uptake of EA into phosphatidylethanolamine (PtdEA). This phenomenon suggests possible biochemical targets of AAL-toxins, which could be enzymes involved in the phospholipid pathway [71].

Based on their chemical structure, AAL-toxins are analogous sphinganine mycotoxins (SAMTs). The SAMTs cause competitive inhibition of ceramide synthase, suppressing the conversion of sphinganine, phytosphingosine, and other free sphingoid bases into complex ceramides. The resulting accumulation of free sphingoid bases acts as a second message that activates programmed cell death (PCD) transduction pathways [72,73]. When sensitive tomato tissues were treated with AAL-toxins, sphinganine and phytosphingosine accumulated in the tissue [74]. However, this phenomenon can be avoided by ceramide supplementation, suggesting that an imbalance of ceramide is critical for triggering cell death $[61,75]$. Further studies have shown that both jasmonic acid (JA) and ethylene can promote AAL-toxin-induced PCD in tomato leaves by interfering with sphingolipid metabolism [76]. AAL-toxin-induced PCD is associated with ceramide signaling and cell cycle disruption. The final physiological effects of AAL-toxins are the development of necrotic lesions on fruits and leaves, the inhibition of in vitro development of calli, pollen, roots, and shoots, and the reduction of protoplast and suspension cell viability [77].

Previous studies on feeding with labeled precursors showed that glycine and the methyl group of methionine were directly incorporated into AAL-toxins. The oxygen groups in the tricarboxylic acid moieties of AAL-toxins were derived from $\mathrm{H}_{2} \mathrm{O}$. The hydroxyl groups of the lipid backbone of the AAL-toxins were derived from molecular oxygen [78]. The AAL-toxin biosynthetic gene ALT1 was identified, which encodes a type I PKS. ALT1 consists of seven domains that include $\alpha$-ketoacyl synthase (KS), acyltransferase (AT), dehydratase (DH), methyl transferase (MT), $\beta$-ketoacyl reductase (KR), enoyl reductase (ER), and acyl carrier protein (ACP) [78]. Recently, a genomic BAC library of the tomato 
pathotype was screened using the ALT1 probe. A $120-\mathrm{kb}$ genomic region includes at least 13 genes involved in the biosynthesis of AAL-toxins. In addition to ALT1, the ALT2, ALT3, ALT6, and ALT13 genes were also identified, encoding cytochrome P450 monooxygenase, aminotransferase, short-chain dehydrogenase/reductase, and $\mathrm{Zn}$ (II)2Cys6 transcription factor, respectively. ALT genes are located on a single small chromosome of about $1.0 \mathrm{Mb}$ in the tomato pathotype strain [9].

\subsection{ACR-Toxins}

Alternaria brown spot disease of rough lemon was first discovered in South Africa [79]. The pathotype RLP (rough lemon) of $A$. alternata is the culprit. It can infect common citrus root species such as rough lemon (Citrus jambhiri Lush.) and rangpur line (C. limonia Osbeck) in some citrus growing areas $[15,18,19]$. The virulence of $A$. alternata RLP is due to the production of ACR-toxins, which may also be called ACRL-toxins [18,31,80,81]. ACR-toxins contain five compounds with different chain lengths, all of which have an $\alpha$-pyrone group (Figure 3). The main form of ACR-toxins (ACR-toxin I, MW = 496) consists of an $\alpha$-dihydropyrone ring in a polyalcohol with 19 carbon atoms [10,31]. ACR-toxins can cause brown necrosis on rough lemon leaves at $0.1 \mu \mathrm{g} \cdot \mathrm{mL}^{-1}$, but did not affect mandarins and other non-hosts even at $1000 \mu \mathrm{g} \cdot \mathrm{mL}^{-1}[18]$.<smiles>CC=C(C)C(O)C(C)C=CC(O)C(C)C(O)CC1CC(O)=CC(=O)O1</smiles>

ACR-toxin I<smiles>CC=C(C)C(O)C(C)C=CC(O)C(C)c1cc(O)cc(=O)o1</smiles>

ACR-toxin III<smiles>CC=C(C)C(O)C(C)C=CC(O)C(C)C(O)Cc1cc(O)cc(=O)o1</smiles>

ACR-toxin II

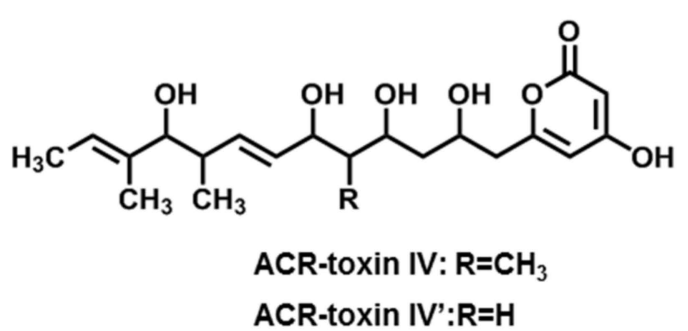

Figure 3. Chemical structures of ACR-toxins.

The target site of ACR-toxins is the mitochondrion, leading to mitochondrial dysfunction in rough lemon. ACR-toxins not only caused the uncoupling of mitochondrial oxidation phosphorylation, but also led to the exit of the cofactor NAD ${ }^{+}$from the TCA (tricarboxylic acid) cycle [82]. The ACRS (ACR-toxin sensitivity gene), which confers sensitivity to ACR-toxins in citrus species, was identified in the mitochondrial genome of rough lemon [83]. The sensitivity was controlled by the post-transcriptional modification of the ACRS transcript.

The rough lemon pathotype strain also carried a small chromosome of $1.2-1.5 \mathrm{Mb}$, and the presence of this chromosome was associated with ACR-toxin production and rough lemon pathogenicity [51]. Several ACRT genes responsible for the biosynthesis of ACR-toxins were identified by sequence analysis of the $1.5 \mathrm{Mb}$ chromosome. ACRTS1, ACRTS2, and ACRTS3 were characterized, encoding a putative hydroxylase, a putative reducing polyketide synthase type I (PKS), and a putative cyclase, respectively. All genes were closely related to ACR-toxin production and pathogenicity $[84,85]$. These genes are unique to the producers of ACR-toxins of the rough lemon pathotype [86]. 


\subsection{AM-Toxins}

Apple cultivars such as Indo and Delicious are highly susceptible to a pathogenic strain of A. alternata f. sp. mali that can cause severe economic losses, especially in Japanese orchards [20,21]. In 1974, AM-toxins were first isolated from A. mali, the apple pathotype of A. alternata that causes apple leaf spot disease, and structural studies were conducted. AMtoxins have three distinct types (I, II, and III. Figure 4) and are produced and released by both germinating conidia and cultured mycelia of the strain. Each toxin is a four-membered cyclic depsipeptide. AM-toxin I is the most abundant among AM-toxins, causing necrosis on leaves of highly susceptible apple cultivars at concentrations of $10^{-8} \mathrm{M}[20,21,87]$.

The plasma membrane and chloroplasts are two targets of AM-toxins for susceptible apple cells [88]. Similar to AK-toxins, AM-toxins can also cause plasma membrane invagination and electrolyte loss. However, the effect of AM-toxins on Japanese pear was weaker than that of AK-toxins [88]. Membrane fragments and vesicles appeared in the chloroplasts, which had emerged from grana lamellae within $3 \mathrm{~h}$ after toxin treatment. Chloroplast disorganization was accompanied by a decrease in chlorophyll content and inhibition of photosynthetic $\mathrm{CO}_{2}$ assimilation [89]. The photosynthetic activity of chloroplasts was inhibited. This phenomenon suggests that the chloroplast is a primary target of AM-toxins $[38,41,90]$.<smiles>[R]C[C@H]1NC(=O)[C@H](C(C)C)OC(=O)[C@H](C)NC(=O)C(=C)NC1=O</smiles>

AM-toxins

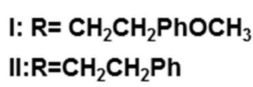

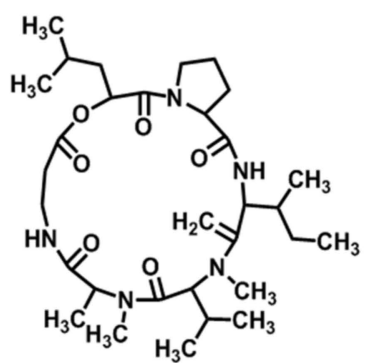

Destruxin B

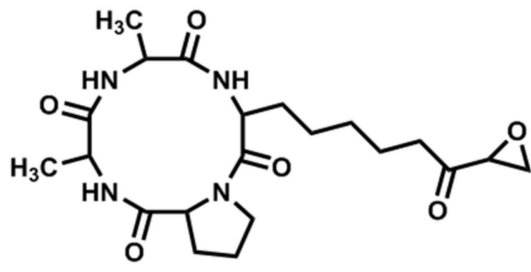

HC-toxin

Figure 4. Chemical structures of AM-toxins, destruxin B, and HC-toxin.

AM-toxins belong to the cyclic peptides that are generally synthesized via nonribosomal pathways by non-ribosomal peptide synthetases (NPRS) [91]. The AMT1, AMT2, AMT3, and AMT4 genes have been successfully isolated encoding proteins resembling enzymes involved in the secondary metabolism and modification of amino acids [92,93]. In 2007, a bacterial artificial chromosome (BAC) was isolated containing four AMT genes and other genes that are upregulated in AM-toxin-producing cultures, suggesting that genes for AM-toxin biosynthesis are clustered in the genome. It also revealed that the AMT genes are located on a conditionally dispensable (CD) chromosome of $<$ with a size of $1.8 \mathrm{Mb}$ in the strain [94].

\subsection{Destruxin B}

Black spot disease of Brassica spp. such as B. campestris and B. napus is caused by A. brassicae (Berk.) Sacc. The symptoms of the disease are lesions with grayish, brownish, or blackish centers and chlorotic margins on all above-ground parts of the plant, especially leaves, stems, and even siliques, resulting in huge economic losses in yields of about $40-60 \%[22,23]$. The oil and protein content of the seeds is also significantly reduced, especially in B. campestris. Destruxin B, a cyclic peptide, is an HST that was first isolated from $A$. brassicae (Figure 4). Subsequent studies revealed that the sensitivity of B. campestris species to destruxin B was variable and that the order of sensitivity to destruxin B was similar to that of the pathogen. It did not cause symptoms in nine plant genera that are not hosts of A. brassicae $[23,95]$. Some researchers suggested that destruxin B may contribute 
to the aggressiveness of $A$. brassicae by conditioning host tissues and thereby determining host susceptibility [96].

However, in black-spot-disease resistant species (Sinapis alba), destruxin B could be converted into a less toxic product, hydroxydestruxin B. Essentially, hydroxydestruxin B was further biotransformed into the $\beta$-D-glucosyl derivative. Remarkably, it was observed that hydroxydestruxin B induced the biosynthesis of phytoalexins in black spot disease resistant species, but not in susceptible species [97].

In addition to phytotoxicity, destruxin B also exhibits a variety of biological activities. For example, significant cytotoxic effects were observed in L1210 leukemia cells and spleen lymphocytes treated with destruxin B [98]. It also showed suppressive effects on hepatitis B virus surface antigen and has been suggested as a potential candidate for the development of new anti-hepatitis agents $[99,100]$. Destruxin B was found to be a specific, dose-dependent, and reversible inhibitor of vacuolar ATPase, which maintains acidity in vacuolar organelles [101].

The biosynthetic pathway of destruxins, including destruxin B, was described in the fungus Metarrhizium anisopliae. Previously, destruxin B was thought to be biosynthesized from protodestruxin by $\mathrm{N}$-methylation [102]. Feeding experiments with isotopically labeled precursors in M. anisopliae showed that methionine was involved in the incorporation of ${ }^{13} \mathrm{C}$ into the $\mathrm{N}$-methyl group of MeVal and MeAla residues. Acetates were involved in the biosynthesis of the $-\mathrm{CH}(\mathrm{OH})-\mathrm{COOH}$ fragment of the hydroxy acid moiety, proline, and isoleucine [103].

\subsection{HC-Toxin}

When northern corn leaf spot disease was first noted in the US in 1938, it was found that Cochliobolus carbonum was the key pathogenic strain and could produce HC-toxin [104]. In the 1970s, Pringle and co-workers purified and partially determined the structure of HC-toxin, indicating that it was a peptide containing Ala and Pro in the ratio of 2:1 [24]. Several years later, the complete structure was established, which was cyclo (D-Pro-L-AlaD-Ala-L-Aeo) (Figure 4), with Aeo standing for 2-amino-9,10-epoxi-8-oxodecanoic acid [25]. In 2013, HC-toxin was also found in the culture filtrates of $A$. jesenskae that was isolated from seeds of Fumana procumbens [26]. HC-toxin could inhibit the root growth of susceptible maize (genotype $h m 1 / h m 1$ ) at $0.5-2 \mu \mathrm{g} \cdot \mathrm{mL}^{-1}$. The concentration needed to affect resistant maize (genotype $\mathrm{Hm} 1 /$-) was 100 -fold higher. The epoxide group of Aeo was critical for HC-toxin toxicity, and other amino acid residues also apparently played important roles in determining the bioactivity [105]. Besides phytotoxicity, HC-toxin also showed cytostatic activity against mammalian cells. The site of action of HC-toxin was histone deacetylase (HD), an enzyme that reversibly deacetylates the core histones (H3 and H4) [106].

HC-toxin production in C. carbonum was controlled by a complex locus, TOX2, that extended over $540 \mathrm{~kb}$ and contained several multicopy genes. The TOX2 locus includes HTS1, TOXA, TOXC, TOXD, TOXE, TOXF, and TOXG genes, which encoded a nonribosomal peptide synthetase, a member of the major facilitator superfamily of transporters, a fatty acid synthase beta subunit, a predicted short-chain alcohol dehydrogenase, a pathwayspecific transcription factor, a putative branched chain amino acid aminotransferase, and an alanine racemase, respectively [26,107]. A. jesenskae had high-scoring orthologs of all known genes involved in HC-toxin biosynthesis from C. carbonum. Based on genomic sequencing, AjTOX2 was considered as a major gene involved in the biosynthesis of HC-toxin in $A$. jesenskae. The genes for HC-toxin biosynthesis were duplicated in these two fungi and the encoded orthologous proteins shared $75-85 \%$ amino acid identity [26].

\subsection{Maculosin}

Spotted knapweed (Centaurea maculosa) is a significant threat as a weed species in North America, particularly in the northwestern United States and southwestern Canada [27,28]. Its invasion of rangelands, roadsides, and pastures has resulted in a decline in forage production of about $70 \%$ and major losses in the millions of dollars. In 1984, an infected 
black-leaved orchid was found in Silver Bow County (Montana, USA), and A. alternata was identified as the causal agent. Although seven diketopiperazines were isolated and identified (Cyclo(-L-Pro-L-Tyr-), Cyclo(-L-Pro-L-Phe-), Cyclo(-L-Pro-D-Phe-), Cyclo-ProHle-), Cyclo(-Pro-Val-), Cyclo(-Pro-Leu-), and Cyclo(-Pro-Ala-)) from the liquid culture of the orchid pathogenic strain of A. alternata, maculosin (Cyclo(-L-Pro-L-Tyr-), Figure 5) was established as a major HST of spotted knapweed because it exhibited high toxicity to spotted knapweed at $10 \mu \mathrm{M}$ but no toxicity to other test plants even at $1 \mathrm{mM}$ [108]. Thus, it has the potential to be developed as a safe and environmentally friendly bioherbicide against knapweed.<smiles>CCCCN1C(=O)NC(Cc2ccc(O)cc2)C1=O</smiles>

Maculosin<smiles>CC(C)(C)[C@H](NC(=O)[C@H](N)CO)C(=O)NCC(=O)N[C@@H](CCC(=O)O)C(=O)O</smiles>

AS-I toxin

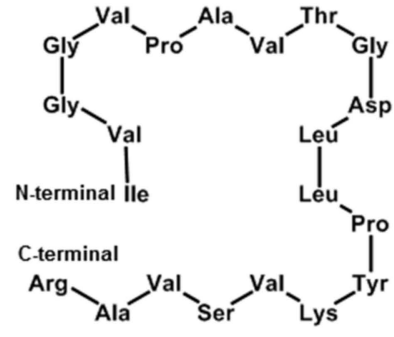

ABR-toxin

Figure 5. Chemical structures of maculosin, AS-I toxin, and ABR-toxin.

The target site of maculosin is the chloroplasts, since within $24 \mathrm{~h}$ of treatment with maculosin there is a progressive decay of the chloroplasts. The core component of maculosin activity is the diketopiperazine ring, which contains proline. Subsequently, the binding component of maculosin was identified as three large molecular weight proteins, one of which was thought to be ribulose-1,5-biphosphate carboxylase (RuBPcase) [109]. Maculosin is also a potent blocker of the delayed-rectifying potassium channel in guinea pig myocytes. It can increase alkaline phosphatase expression, induce differentiation, and exert antibacterial and antioxidant effects $[110,111]$. To date, there is no report on the biosynthetic pathway of maculosin. A systematic, in-depth study has yet to be conducted.

\subsection{AS-I Toxin}

In 1997, two phytotoxins were isolated from the culture filtrate of $A$. alternata that are pathogenic to sunflowers [29]. The chemical structure of one toxin was deduced using chemical and physicochemical methods as tetrapeptide Ser-Val-Gly-Glu and named as AS-I toxin (Figure 5). AS-I toxin can cause chlorosis or necrosis on leaves, inhibit seed germination of sunflowers, and lead to mild toxicity on tobacco and zucchini leaves, but has no toxic effect on other plants. These phenomena suggest that AS-I toxin is an HST [29,38]. The mode of action, target, and biosynthetic pathway for AS-I toxin are still not clear, so there is a wide research scope for this HST.

\subsection{ABR-Toxin}

Most HSTs are low-molecular-weight compounds and were discovered in liquid cultures. In 2008, some researchers indicated that the spore suspensions of $A$. brassicae can cause gray leaf spot disease on Brassica plants. After collecting spore germination fluid (SGF) on leaves, a fraction with a high molecular weight (above $10 \mathrm{kDa}$ ) and toxicity to host leaves was separated by ultrafiltration. Next, a new toxin was purified from that fraction by chromatography and named ABR-toxin. Further investigation showed that ABR-toxin was a protein toxin that loses its toxicity when treated at $60^{\circ} \mathrm{C}$ or with proteinase $\mathrm{K}$ for $15 \mathrm{~min}$. The isoelectric point of ABR-toxin was about 7.0 and the molecular weight was $27.5 \mathrm{kDa}$. It contains 21 amino acid residues (Ile-Val-Gly-Gly-Val-Pro-Ala-Val-Thr-GlyAsp-Leu-Leu-Pro-Tyr-Lys-Val-Ser-Val-Ala-Arg) with an unblocked N-terminus (Figure 5). Biological activations showed that ABR-toxin at a concentration of $0.5-1 \mu \mathrm{g} \cdot \mathrm{mL}^{-1}$ could induce symptoms on Brassica leaves, but a concentration greater than $50 \mu \mathrm{g} \cdot \mathrm{mL}^{-1}$ had 
no effect on non-host leaves. ABR-toxin at a concentration of $0.5-1 \mu \mathrm{g} \cdot \mathrm{mL}^{-1}$ mixed with non-pathogenic spores of $A$. alternata could lead to symptoms similar to those caused by $A$. brassicae infection. The above results show that ABR-toxin not only triggered the initial colonization of host plants, but also showed a relationship with disease development that was different from that of destruxin B [23]. Currently, there are very few studies on ABR-toxin, so further detailed studies need to be conducted.

\section{Non-Host-Selective Toxins}

So far, less attention has been paid to NHSTs of Alternaria compared to HSTs. However, the role of NHSTs in virulence is more complex than that of HSTs. An in-depth exploration of NHSTs may reveal new and unexpected aspects for applications in many fields. Here, we detected 50 NHSTs from six families of Alternaria, including pyranones, quinones, tertramic acid, cyclic peptides, macrolides, and phenols (Table 2).

Table 2. NHSTs produced by Alternaria species.

\begin{tabular}{|c|c|c|c|}
\hline Family & Toxins & Alternaria Species & References \\
\hline \multirow[t]{13}{*}{ Pyranones } & Radicinin & A. radicina & [112] \\
\hline & Radicinol & A. radicina, $A$. chrysanthemi & {$[112,113]$} \\
\hline & 3-epiradicinol & A. chrysanthemi, A. longipipes & {$[113,114]$} \\
\hline & Deoxyradicinin & A. helianthi & [114] \\
\hline & Pyrenocine A & A. helianthi & [115] \\
\hline & Pyrenocine B & A. helianthi & [115] \\
\hline & Solanapyrones A & A. solani & [116] \\
\hline & Solanapyrones B & A. solani & [116] \\
\hline & Solanapyrones C & A. solani & [116] \\
\hline & Solanapyrones $\mathrm{P}$ & A. tenuissima & [117] \\
\hline & Alternariol & A. tenuis & [118] \\
\hline & Alternariol 9-methyl ether & A. tenuis & [118] \\
\hline & Altenuene & A. tenuis & [118] \\
\hline \multirow[t]{27}{*}{ Quinones } & Altertoxin I & A. tenuis & [119] \\
\hline & Altertoxin II & A. tenuis & [119] \\
\hline & Altertoxin III & A. alternata & [120] \\
\hline & Altertoxin IV & A. tenuissima & [121] \\
\hline & Altertoxin V & A. tenuissima & [122] \\
\hline & Altertoxin VI & A. tenuissima & [122] \\
\hline & Altertoxin VII & Alternaria sp. PfuH1 & [123] \\
\hline & Alterlosins I & A. alternata & [124] \\
\hline & Alterlosins II & A. alternata & [124] \\
\hline & Alteichin & A. eichorniae & [120] \\
\hline & Stemphyperylenol & A. alternata & [125] \\
\hline & Stemphyltoxin III & A. alternata & [125] \\
\hline & Altersolanol A & A. solani & [126] \\
\hline & Altersolanol B & A. solani & [126] \\
\hline & Altersolanol C & A. solani & [127] \\
\hline & Altersolanol E & A. solani & [127] \\
\hline & Altersolanol F & A. solani & [127] \\
\hline & Macrosporin & A. solani & [126] \\
\hline & Bostrycin & A. eichhorniae & [128] \\
\hline & 4-Deoxybostrycin & A. eichhorniae & [128] \\
\hline & Physcion & A. porri & [129] \\
\hline & Erythroglaucin & A. porri & [129] \\
\hline & Alterporriol B & A. porri & [130] \\
\hline & Alterporriol K & Alternaria sp. ZJ9-6B & [130] \\
\hline & Alterporriol L & Alternaria sp. ZJ9-6B & [130] \\
\hline & Alterporriol M & Alternaria sp. ZJ9-6B & [130] \\
\hline & Alterporriol T & Alternaria sp. XZSBG-1 & [131] \\
\hline
\end{tabular}


Table 2. Cont.

\begin{tabular}{|c|c|c|c|}
\hline Family & Toxins & Alternaria Species & References \\
\hline \multirow{3}{*}{ Tertramic acid } & Tenuazonic acid & A. alternata, $A$. longipes, $A$. tenuissima & [132] \\
\hline & 3-acetyl-5-isopropyltetramic acid & A. tenuis & [133] \\
\hline & 3-acetyl-5-isobutyltetramic acid & A. tenuis & [133] \\
\hline Cyclic peptides & Tentoxin & A. alternata, $A$. citri, $A$. longipes, $A$. mali, A. porri, A. tenuis & [134-139] \\
\hline \multirow[t]{3}{*}{ Macrolides } & Brefeldin A & A. carthami, A. zinnia & {$[140,141]$} \\
\hline & 7-Dehydrobrefeldin A & A. carfhami & [141] \\
\hline & Aldaulactone & A. dauci & [142] \\
\hline \multirow[t]{3}{*}{ Phenolics } & Zinniol & $\begin{array}{c}\text { A. zinnia, A. dauci, A. tagetica, A. solani, A. porri, A. carthami, } \\
\text { A. macrospora, A. cichorii }\end{array}$ & {$[143-145]$} \\
\hline & $\alpha$-Acetylorcinol & A. tenuissima, A. brassicicola, A. dauci & [146] \\
\hline & $p$-Hydroxybenzoic acid & A. tagetica, A. dauci & {$[146,147]$} \\
\hline
\end{tabular}

\subsection{Pyranones}

Pyranone is an important natural product that has attracted considerable attention due to its intriguing stereoisomeric structure and impressive bioactivity [148]. Simple pyranones and dibenzopyranones are the major groups of the pyranone family produced by Alternaria spp.

\subsubsection{Simple Pyranones}

Pyranones without a benzene ring structure are defined as simple pyranones [6]. For the NHSTs of Alternaria, we have described here ten simple pyranones (Figure 6).

Radicinin was first found from Stemphylium radicinum [149] and then also isolated from $A$. radicina, including its analogue radicinol [112]. So far, many new simple pyranones NHSTs have been found in Alternaria spp. Radicinol and 3-epiradicinol have been isolated from other strains, such as $A$. chrysanthemi, which causes leaf spot disease in Leucanthemum maximum [113]. Further, 3-Epiradicinol is also found in A. longipipes. Deoxyradicinin was found in A. helianthi, an aggressive pathogen of sunflower (Figure 6a) [114].

Pyrenocine A and pyrenocine $\mathrm{B}$ were first described as products of the onion pink root fungus Pyrenochaeta terrestris [150]. They were then also found in the liquid medium of $A$. helianthi isolated from Helianthus tuberosus leaves with necrotic lesions. Pyrenocine A proved to be lethal to both isolated protoplasts and whole leaf tissue of Helianthus (Figure 6a) [115].

Solanapyrones A-C were isolated in 1983 from the phytopathogenic fungus A. solani, the causal agent of early potato blight [116]. Recently, solanapyrone P was discovered from A. tenuissima, an endophytic fungus in Salvia przewalskii (Figure 6a) [117].

Most compounds from this family showed lower phytotoxicity than radicinin [151]. Radicinin was found to be toxic to Coix lachryma-christi at $0.3 \mu \mathrm{g} \cdot$ leaf $^{-1}$ [152]. It caused a $25 \%$ inhibition in root growth of carrot seedlings at a concentration of $10 \mu \mathrm{g} \cdot \mathrm{mL}^{-1}$ [153]. In the structure of radicinin, the $\alpha, \beta$-unsaturated carbonyl group at C-4, a free secondary hy-droxyl group at C-3, and the stereochemistry of the same carbon and the unsaturation of the propenyl side chain play key roles to exhibit activity [151]. Due to its targeting activity against the host plant and the fact that it shows no toxicity to zebrafish embryos, radicinin has the potential to be developed as a natural bioherbicide [151]. As another bioactivity, radicinin exhibits antifungal, insecticidal, and antibiotic activity against Gram-positive bacteria, including Staphylococcus aureus and Clostridium sp. [152,154].

Radicinol showed anticancer activity in various cancer cells due to modulating both tumor suppressor protein (p53) and antiapoptic protein (BCL-2), which in turn increased the expression of caspase-3 [155]. 
<smiles>C/C=C/c1cc2oc(C)c(O)c(=O)c2c(=O)o1</smiles>

Radicinin<smiles>C/C=C/c1cc2c(c(=O)o1)C(=O)CC(C)O2</smiles><smiles>[R]C1C=C([C@H]2C(C)C=C[C@H]3CCCC[C@@]23C)OC(=O)C1[R]</smiles><smiles>C/C=C/c1cc2c(c(=O)o1)[C@@H](O)[C@H](O)[C@H](C)O2</smiles>

Radicinol<smiles>C/C=C/C(=O)c1c(OC)cc(=O)oc1C</smiles>

Pyrenocine A<smiles>C/C=C/c1cc2c(c(=O)o1)C(O)C(O)C(C)O2</smiles><smiles>COc1cc(=O)oc(C)c1C(=O)CC(C)O</smiles>

Pyrenocine B<smiles>C[C@H]1C=C[C@H]2C[C@H](O)CC[C@]2(C2=CC(=O)CCO2)[C@H]1C</smiles>

Solanapyrone P<smiles>Cc1cc(O)cc2oc(=O)c3c(O)cc(O)cc3c12</smiles>

Alternariol<smiles>COc1cc(O)c2c(=O)oc3cc(O)cc(C)c3c2c1</smiles>

Alternariol 9-methyl ether<smiles>COc1cc(O)c2c(c1)C1=CC(O)[C@H](O)C[C@]1(C)OC2=O</smiles>

Altenuene

Figure 6. Chemical structures of Alternaria NHSTs belonging to simple pyranones (a) and dibenzopyranones (b) families.

Pyrenocine A caused leaf necrosis in the leaf injury bioassay and inhibited the growth of many plants, especially greater foxglove and autumn crocus. Pyrenocine A and B induced significant electrolyte loss in the leaf tissue of bermuda grass. However, pyrenocine B showed much weaker phytotoxic activity than pyrenocine A [156]. Moreover, pyrenocine A exhibited cytotoxicity against cancer cells with an $\mathrm{IC}_{50}$ value of 2.6-12.9 $\mu \mathrm{M}$ [157]. Pyrenocine B inhibited the gene presentation of primary dendritic cells (DCs) in mice [158].

Solanapyrone A and B showed phytotoxicity in chickpea, resulting in stem death. Solanapyrone A was more toxic than solanapyrone B [159]. Solanapyrone A, C, and P showed antibacterial activities against various bacteria such as Bacillus subtilis, B. megaterium, Clostridium perfringens, Micrococcus tetragenus, and Escherichia coli with minimum inhibitory concentrations (MIC) ranging from 12.5 to $100 \mu \mathrm{g} \cdot \mathrm{mL}^{-1}$ [117]. Solanapyrone A can also inhibit mammalian DNA polymerase $\beta$ and $\lambda$ activities in vitro, with $\mathrm{IC}_{50}$ values of $30 \mu \mathrm{M}$ and $37 \mu \mathrm{M}$, respectively [160].

Among these simple pyranones, the biosynthetic pathway of solanapyrone A was also discovered. Feeding experiments with $\left[1-{ }^{13} \mathrm{C}\right],\left[1,2-{ }^{13} \mathrm{C}\right]$ acetates, and $\left[\mathrm{S}^{13} \mathrm{CH}_{3}\right]$ methionine showed that solanapyrones were biosynthesized from an octaketide consisting of one acetylCoA, seven malonyl-CoA, and two one-carbon units from methionine [161]. Recently, a gene cluster for solanapyrone biosynthesis containing six genes, SOL1-SOL6, was identified for the first time in $A$. solani, suggesting that solanapyrone biosynthesis requires eight acetates and one S-adenosylmethionine (SAM) as precursors [162]. Of these genes, SOL1 encodes a polyketide synthase that initiates the solanapyrone biosynthetic pathway, and 
SOL5 encodes a Diels alderase that catalyzes both the oxidation and subsequent cyclization of the immediate precursor compound of solanapyrone A [163].

\subsubsection{Dibenzopyranones}

The dibenzopyranone skeleton is found in many natural products and biologically active molecules. Dibenzopyranone is of great importance as an intermediate for several interesting bioactive compounds [6,164]. In this section, the three major dibenzopyranones produced by Alternaria are presented, namely alternariol $(\mathrm{AOH})$, alternariol-9-methyl ether (AME), and altenuol (ALT) (Figure 6b).

$\mathrm{AOH}, \mathrm{AME}$, and ALT are structurally related mycotoxins produced by different Alternaria strains, such as A. tenuis $[118,132]$. AOH and AME were first isolated and described in 1953 [165], while ALT was discovered in 1971 [118]. Subsequent studies showed that these three compounds are present in a wide range of vegetables, fruits, mushrooms, cereals, grapes, and feeds $[132,166,167]$. AOH and AME are considered to be the most important Alternaria toxins because they are produced in relatively large amounts by most species and account for up to $20 \%$ of crude extracts of Alternaria isolates, while ALT accounts for only $1-3 \%$ of extracts $[119,168]$.

$\mathrm{AOH}$ and AME possess broad cytotoxicity, genotoxicity, and can induce oxidative stress [169-173]. In vitro, AOH and AME showed cytotoxicity to Henrietta Lacks's cervical cancer cell line HeLa cells [119]. Further studies revealed that AOH was cytotoxic to human colon carcinoma cell lines [174] and Caco-2 cells [172]. It effectively inhibited DNA relaxation and stimulated DNA cleavage activities of topoisomerase I, II $\alpha$, and II $\beta$ [170] and had mutagenic activity in mammalian cell lines [175]. AOH was also able to induce autophagy and senescence in murine macrophages and alter the morphology and cytokine secretion of murine and human macrophages [176,177]. In 1992, it was suggested that $\mathrm{AOH}$ and $\mathrm{AME}$ on cereals may be the most important factors for the increased incidence of human esophageal cancer in Linxian County, China [178]. Both AOH and AME appear to be highly mutagenic in the assay of B. subtilis and E. coli ND -160 [179]. Due to their widespread occurrence and high toxicity, the European Food Safety Authority (EFSA) has set the threshold of toxicological concern (TTC) for AOH and AME at $2.5 \mathrm{ng} \cdot \mathrm{kg}^{-1}$ body weight per day [180]. ALT is most acutely toxic in female mice with a $\mathrm{LD}_{50}>50 \mathrm{mg} \cdot \mathrm{kg}^{-1}$ body weight, compared to $\mathrm{AOH}$ and $\mathrm{AME}$ with a $\mathrm{LD}_{50}>400 \mathrm{mg} \cdot \mathrm{kg}^{-1}$ body weight [181]. Recently, ALT was reported to exhibit cytotoxic activity against HCT116 cell lines with an $\mathrm{IC}_{50}$ value of $3.13 \mu \mathrm{M}$, and thus has the potential to be developed as a new antitumor drug candidate [182].

As for phytotoxic activity, $\mathrm{AOH}$ possessed a significant cytotoxic activity in soybean cells with an $\mathrm{EC}_{50}$ value of $4.69 \mu \mathrm{M}$. It was suggested that the phenolic hydroxyl group played a key role in the toxicity to soybean cell culture [183]. AOH inhibited root growth of Pennisetum alopecuroides, Medicago sativa, and Amaranthus retroflexus at $1000 \mu \mathrm{g} \cdot \mathrm{mL}^{-1}$ [184]. AME inhibited the electron transport chain of spinach chloroplasts with an $\mathrm{IC}_{50}$ value of $29.1 \mu \mathrm{M}$, and inhibited the growth of Synechococcus by directly interacting with one or more of the electron carriers involved in the electron transport chain [185]. Although there are reports of genotoxic, estrogenic, and mutagenic effects in laboratory animals, the toxicity of $\mathrm{AOH}$ and AME to humans and animals is low. Thus, these compounds represent a new lead structure and have the potential to be developed as new herbicides for weed control [185].

$\mathrm{AOH}, \mathrm{AME}$, and ALT are all polyketide-derived compounds. Due to their structural similarity, the biosynthetic pathway of these compounds should be of importance. The biosynthetic pathway of AOH was first studied in detail in 1961, which suggested that $\mathrm{AOH}$ could be synthesized by head-tail condensations of acetate units [186]. Further studies revealed that the formation of $\mathrm{AOH}$ occurs by the polycondensation of malonate, which is formed by the carboxylation of acetate [187]. Later, an enzyme, alternariol-Omethytransferase from A. alternata, was isolated that converts AOH to AME [188]. In 2019, the gene cluster for the biosynthesis of $\mathrm{AOH}$ and several derivatives of A. alternata was 
found. The gene cluster contains PSKI, OMTI, MOXI, SDRI, and DOXI, which encode Omethyltransferase, FAD-dependent monooxygenase, short-chain dehydrogenase, putative extradiol dioxygenase, and estradiol dioxygenase, respectively. Production begins with PKSI assembling an acetyl-CoA, together with six malonyl-CoA, to form the heptaketide $\mathrm{AOH}$. $\mathrm{AOH}$ is further converted to AME by the methyltransferase OMTI. Next, 4-hydroxyAME is catalyzed as an intermediate by the monooxygenase MOXI, followed by the opening of the lactone ring by SDRI to form altenusin. Finally, the formation of ALT from altenusin was catalyzed by DOXI for the rotation of the C-ring and lactonization [189].

\subsection{Quinones}

Quinones are an important species that interact with biological systems to promote many beneficial agents or even induce toxicities [190]. Among Alternaria toxins, there are three groups of quinones, including perylenequinones, anthraquinones, and bianthraquinone derivatives that have been isolated so far. In this section, twelve perylenequinones, ten anthraquinones, and five bianthraquinones, as well as their unique bioactivities, are presented.

\subsubsection{Perylenequinone Derivatives}

Perylenequinones are a class of aromatic polyketides characterised by a highly conjugated pentacyclic core that gives them their potent bioactivity [191]. Here, twelve perylenequinones produced by Alternaria are presented, including altertoxin I-VII, alterlosin I and II, alteichin, stemphyperylenol, and stemphyltoxin III.

There are many types of altertoxins (ATXs) (Figure 7). We have described seven types of ATXs from Alternaria spp. ATX I and ATX II were first isolated from A. tenuis in 1973 and ATX III was isolated from A. alternata in $1983[119,120]$. The correct structure of ATX I was elucidated in 1983 [120]. ATX IV was isolated from the fermentation broth of an endophytic strain of A. tenuissima living in the stem of Tribulus terrestris [121]. ATXV and VI were isolated from the fermentation broth of $A$. tenuissima QUE1Se, which inhabits the stem tissue of Quercus emoryi [122]. Recently, ATX VII was isolated from the endophytic fungus Alternaria spp. PfuH1 of patchouli (Pogostemon cablin). Further studies showed that all of them are perylene derivatives, which can also be produced by other Alternaria spp. including A. mali and A. eichorniae. Although ATXs were produced in very low amounts by only a few species, they were important Alternaria toxins due to their high toxicity [168]. Among them, ATX II was the most potent [175,192].<smiles>O=C1CC(O)C23c4c(ccc(O)c4C2(O)C1)-c1ccc(O)c2c1C3(O)CCC2=O</smiles>

Altertoxin I<smiles>O=C1CC[C@]2(O)c3c(ccc(O)c31)-c1ccc(O)c3c1C2[C@@]3(O)C1CC1</smiles>

Altertoxin I

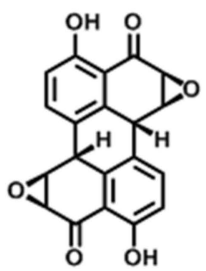

Altertoxin III<smiles>Oc1ccc2c3c1C(O)C1O[C@H]1[C@@H]3O[C@H]2c1ccc(O)c2c1[C@H]1O[C@H]1[C@H]2O</smiles>

Altertoxin IV<smiles>O=C1C[C@H](O)[C@H]2c3c1ccc(O)c3C(=O)C1OC12</smiles>

Altertoxin V<smiles>O=C1C=CC2c3c(ccc(O)c31)-c1ccc(O)c3c1C2C1OC1C3=O</smiles>

Altertoxin VI<smiles>O=C1C=CC2(O)C(=O)c3c(O)ccc4c3C(O)(c3ccc(O)c(c32)C1=O)[C@H](O)C4O</smiles>

Altertoxin VII<smiles></smiles>

Alterlosin I

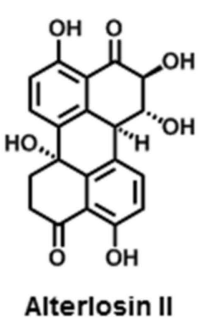



Alteichin

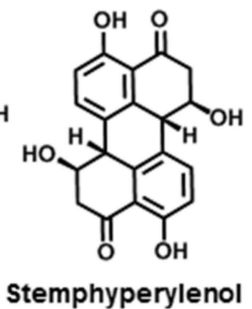

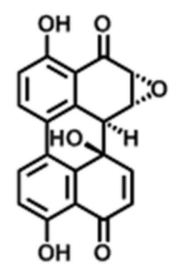

Stemphyltoxin III

Figure 7. Chemical structures of Alternaria NHSTs belonging to perylenequinone family. 
ATXs showed many activities; in particular, ATX I-III showed significant cytotoxicity, mutagenicity, and possibly carcinogenicity. In an Ames test, ATX I-III proved to be clearly mutagenic in TA98, TA100, and TA1537, with a ranking of ATX I < ATX II < ATX III [193]. ATX I and II were found to be highly toxic to the HeLa cells, with $\mathrm{IC}_{50} \mathrm{~s}$ of 20 and $0.5 \mu \mathrm{g} \cdot \mathrm{mL}^{-1}$, respectively [119]. ATX I-III were all cytotoxic to Chinese hamster V79 cells at concentrations greater than $5,0.02$, and $0.2 \mu \mathrm{g} \cdot \mathrm{mL}^{-1}$, respectively $[175,194]$. ATX IV showed cytotoxicity to human osteosarcoma cell lines (MG-63) and human hepatocellular carcinoma cell lines (SMMC-7721), with an $\mathrm{IC}_{50}$ at 14.81 and $22.87 \mu \mathrm{g} \cdot \mathrm{mL}^{-1}$, respectively [195]. ATX V and VI showed the ability to inhibit HIV-1 viral replication in A3.01-infected cells. ATX V showed higher activity and could completely inhibit HIV-1 virus replication at concentrations of $0.5 \mu \mathrm{M}$. Thus, they have the potential to be developed as potent anti-HIV drugs [122]. ATX VII showed antibacterial activities against $S$. agalactiae with MIC values of $17.3 \mu \mathrm{g} \cdot \mathrm{mL}^{-1}$ [123].

As the major NHSTs of Alternaria, the biosynthetic pathway of ATXs was revealed. Based on the feeding experiment with ${ }^{13} \mathrm{C}$-labelled precursors, ATX I was used as an example of the biosynthetic pathway of ATXs. Five acetate molecules were found to be used for the synthesis of octalone analogues and tetralone analogues. ATXs were synthesised by the oxidative coupling of two molecules of tetralone analogues [120].

Alterlosins (ALS) include two compounds (Figure 7), ALS I and II. They were first isolated in 1989 from a host-selective strain of A. alternata, which is pathogenic on spotted knapweed. Both exhibited reasonable phytotoxicity, and ALS II was more potent than ALS I. ALS II was able to cause necrotic lesions on knapweed, lettuce, and Johnson grass at $10^{-4} \mathrm{M}$ [124].

Alteichin (ALTCH) was isolated from A. eichorniae (Figure 7), a fungal pathogen of water hyacinth $[120,196]$. ALTCH was shown to have antifungal activity against Valsa ceratosperma and caused growth inhibition in lettuce seedlings [120]. Further studies revealed that ALTCH at a concentration of $0.1 \mathrm{mg} \cdot \mathrm{mL}^{-1}$ could induce necrotic spots on the leaves of water hyacinth, tomato thistle, wheat, sunflower, and barley within $12 \mathrm{~h}$. The target of ALTCH can act directly on the plant cell and cause structural changes in plant membranes [196].

Stemphyperylenol and Stemphyltoxin III could be found in the culture of Stemphylium botryosum and A. alternata (Figure 7) [124,125]. Based on the bioactivity studies, stemphyperylenol is a toxin for finger millet [197]. Stemphyltoxin III showed an in vitro antibacterial activity against $B$. subtifis, B. cereus, and E. coli, as well as phytotoxic activity (Arnone et al., 1986). SOTTX-III was also mutagenic against Ames S. typhimurium TA98 and TA1537 [125,198].

\subsubsection{Anthraquinone Derivatives}

Anthraquinones (9,10-dioxoanthracenes), with the rigid planar tricyclic aromatic system anthracene, form an important class of valuable natural products [199]. There are many Alternaria NHSTs belonging to this family (Figure 8a).

Altersolanol A-C, E, F, and macrosporine could be isolated from A. solani, a pathogen of solanaceous plants. Altersolanol A and B occurred only in the culture filtrate, while the others could be isolated from either the culture filtrate or mycelia $[126,127,200]$. Bostrycin and 4-deoxybostrycin were isolated from the culture filtrate of A. eichhorniae [128]. Physcion and erythroglaucin were isolated from A. porri [129]. 

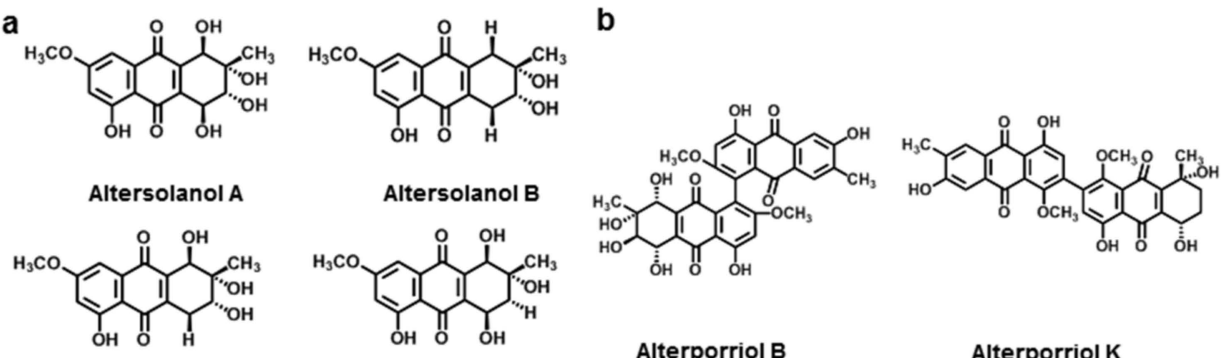

Alterporriol B

Alterporriol K
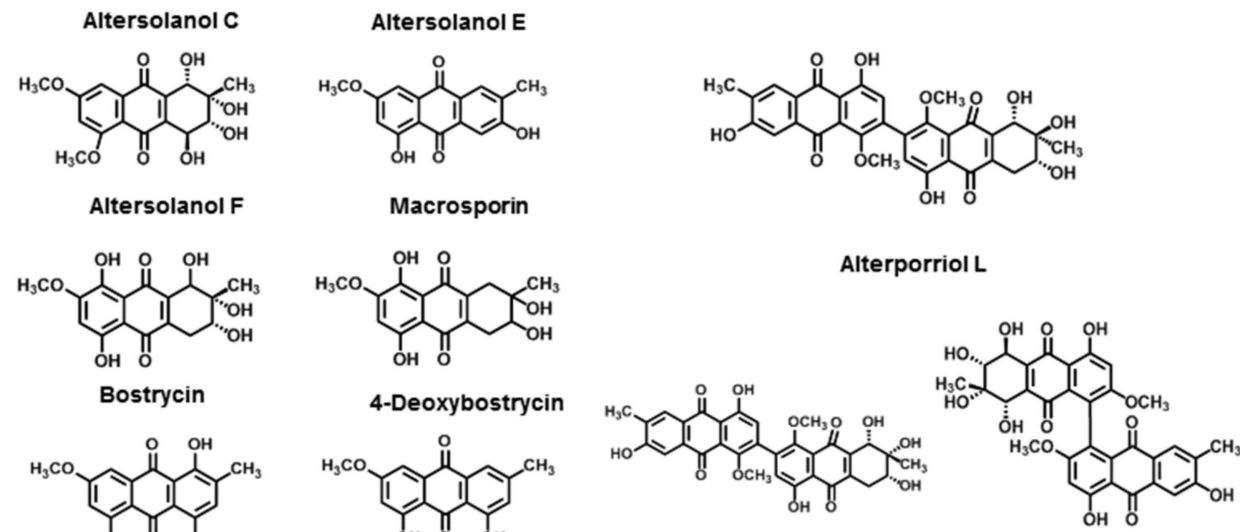

Erythroglaucin

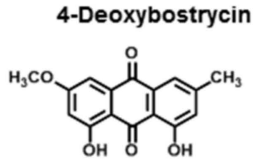

Physcion

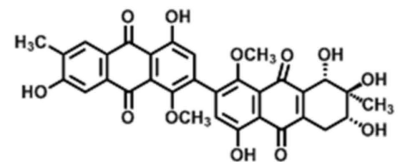

Alterporriol M

Figure 8. Chemical structures of Alternaria NHSTs belonging to anthraquinone (a) and bianthraquinone (b) families.

In bioactivity studies, altersolanols $\mathrm{A}$ and $\mathrm{B}$ showed an inhibitory effect on lettuce and stone-leek seedlings [201]. Altersolanol A-C, E, and F could act as electron transport inhibitors in the mitochondria of tobacco [202]. Altersolanol A could also cause necrosis and twisting on tomato leaves [203]. Besides phytotoxicity, altersolanols A-C and E showed antimicrobial activity against $S$. aureus, B. subtilis, M. luteus, and Pseudomonas aeruginosa. Altersolanols F showed obvious inhibitory activity against HCT-116 and HeLa cell lines with the $\mathrm{IC}_{50}$ values of 3.026 and $8.094 \mu \mathrm{M}$, respectively [131]. Recent studies showed that altersolanol A exhibited cytotoxicity in vitro against 34 human cancer cell lines with an $\mathrm{IC}_{50}\left(\mathrm{IC}_{70}\right)$ value of $0.005 \mu \mathrm{g} \cdot \mathrm{mL}^{-1}\left(0.024 \mu \mathrm{g} \cdot \mathrm{mL}^{-1}\right)$. Altersolanol A was a kinase inhibitor that induced cell death by apoptosis via the cleavage of caspase- 3 and -9 and a decrease in the expression of anti-apoptotic proteins $[195,204]$.

Macrosporine exhibited antibacterial and phytotoxic activity, inhibiting Candida albicans, B. subtilis, and S. aureus at a dose of $200 \mu \mathrm{g} \cdot \mathrm{disc}^{-1}$, and induced significant necrosis by singlet oxygenation in plants [205].

Bostrycin and 4-deoxybostrycin showed antibacterial activity against B. subtilis. Bostrycin was also able to inhibit the growth of Mycobacterium tuberculosis in vitro and inhibit the activity of effector protein tyrosine phosphatase (MptpB) secreted by Mtb. In addition, bostrycin also acted as an antitumor agent against various cancer cell lines [206-209]. Both toxins showed a phytotoxic effect on water hyacinth at a concentration of 7 and $30 \mu \mathrm{g} \cdot \mathrm{mL}^{-1}$, respectively [128].

Physcion had various pharmacological properties such as anti-inflammatory, antimicrobial, and antitumor effects, including cytotoxic activity in HeLa, A549, HL-60, and SW680 cells [210]. Physcion showed no mutagenicity in an Ames assay with TA100 and TA2638 [211]. The phytotoxic activity of physcion showed that it inhibited root and hypocotyl growth less at $7.0 \times 10^{-4} \mathrm{M}$ in green amaranth and timothy [212].

Erythroglaucine showed a DPPH (1,1-diphenyl-2-picrylhydrazyl) radical scavenging property with an $\mathrm{IC}_{50}$ value of $62 \mu \mathrm{g} \cdot \mathrm{mL}^{-1}$ [213].

Based on the incorporation experiment of ${ }^{13} \mathrm{C}$-labelled sodium acetate and acetate, ageolanol A, macrosporin, and other similar pigments of $A$. porri were formed by eight 
acetates, which were condensed in a head-to-tail process to generate a linear octaketide. Subsequent cyclization and enolization, decarboxylation, and oxidation produced the final anthraquinone analogues [214,215].

\subsubsection{Bianthraquinone}

Many Alternara spp. can produce alterporriol, a member of the bianthraquinone derivatives (Figure 8b). Alterporriol B was first described in A. porri in 1984. To date, many alterporriols have been discovered in Alternaria. Alterporriol K, L, and $\mathrm{M}$ were obtained from the extracts of Alternaria sp. ZJ9-6B and showed moderate cytotoxic activity against MDA-MB-435 and MCF-7 cells with $\mathrm{IC}_{50}$ values ranging from 13.1 to $29.1 \mu \mathrm{M}$ [130]. Alterporriol T was found in Alternaria sp. XZSBG-1 and showed an inhibition of $\alpha$-glucosidase with an $\mathrm{IC}_{50}$ value of $7.2 \mu \mathrm{M}$ [131].

Some evidence suggests that preanthraquinones serve as precursors for a number of dimers. Alterporriols are homodimers composed of two alterolanols. Alterporriol A, for example, is formed by the oxidative coupling of a macrosporin and an alterolanol A. Other alterporriols can also be biosynthesized by the same pathways as alterporriol A [214].

\subsection{Tertramic Acids}

Although they were isolated in the early 20th century, the various biological functions of tetramic acids (2,4-pyrrolidinediones) were not discovered until the 1960s [216]. Tenuazonic acid, 3-acetyl-5-isopropyltetramic acid, and 3-acetyl-5-isobutyltetramic acid are three classical analogues produced by Alternara [133].

Tenuazonic acid (TeA, (5S)-3-acetyl-5[(2S)-butan-2-yl]-4-hydroxy-1,5-dihydro-1H-pyrrol2-one, Figure 9), an amide metabolite originally isolated from the culture filtrate of A. tenuis, is the simplest compound of the tetramic acids $[217,218]$. The structure and absolute configuration of $\mathrm{TeA}$ were elucidated after TeA was degraded by ozonolysis followed by acid hydrolysis [219]. Subsequently, TeA was also found in other species, such as Phoma sorghina, Magnaporthe oryzae, Aspergillus spp., and Alternaria spp., especially in A. alternata, A. longipes, and A. tenuissima [81,132,220-224]. Since its first isolation from cotton, TeA has been found in various vegetable, fruit, and crop plants contaminated with Alternaria [225-227].<smiles>CC[C@H](C)C1NC(=O)C(C(C)=O)=C1O</smiles>

Tenuazonic acid<smiles>CC(=O)C1=C(O)C(C(C)C)NC1=O</smiles>

3-acetyl-5-isopropyltetramic acid<smiles>CC(=O)C1=C(O)C(CC(C)C)NC1=O</smiles>

3-acetyl-5-isobutyltetramic acid

Figure 9. Chemical structures of Alternaria NHSTs belonging to the tertramic acids family.

TeA has long been reported to be toxic in animals, exhibiting antibacterial, antiviral, anticancer, and phytotoxicity effects [224,228-231]. The oral median lethal dose for male and female mice is $182 \mathrm{or} 225 \mathrm{mg} \cdot \mathrm{kg}^{-1}$ and $81 \mathrm{mg} \cdot \mathrm{kg}^{-1}$ body weight, respectively [228,232]. It is also toxic to chicken embryos [233]. TeA inhibits protein biosynthesis by inhibiting the release of the polypeptide from the ribosome [234]. EFSA has evaluated the toxicity of TeA and set the threshold of toxicological concern at $1500 \mathrm{ng} \cdot \mathrm{kg}^{-1}$ body weight per day [235]. The first study on the effect of TeA on plant cells and seedlings was published in 1974. TeA could not only cause a necrotic spot on rice leaves, but also showed a striking stunting effect on the seedling growth of rice plants, mung beans, radishes, and turnips, as well as on the growth of cells of soybean and rice plants grown in suspension [236]. In the last two decades, an increasing number of articles have reported its phytotoxicity. TeA showed an inhibitory activity against 4-hydroxyphenylpyruvate dioxygenase (HPPD) with an $\mathrm{IC}_{50}$ 
of $18 \mu \mathrm{M}$ [237] and plant plasma membrane (PM) $\mathrm{H}^{+}$-ATPase [238]. TeA was also able to inhibit the elongation of seedling roots and shoots [239-241], and resulted in a significant increase in multi-nucleolus of Vicia faba root tip cells at $400 \mu \mathrm{g} \cdot \mathrm{mL}^{-1}$ [242]. Qiang et al. found a crude extract named AAC-toxin containing $5 \%$ TeA produced by A. alternata, the natural pathogen of Ageratina adenophora, a common noxious weed worldwide. Further purification of the AAC-toxin and subsequent bioassays showed that TeA was primarily responsible for herbicidal activity. It exhibited broad spectrum weed activity. Thus, TeA had the potential to be used as a bioherbicide in cotton fields [224,243-246].

Detailed studies on the main mechanism of action of TeA phytotoxicity revealed that TeA is a novel inhibitor of photosystem II (PSII), disrupting electron flow beyond the primary quinone acceptor, $\mathrm{Q}_{\mathrm{A}}$, by interacting with the D1 protein in the PSII reaction centers. The pyrrole ring, which contains an $\mathrm{N}-\mathrm{C}=\mathrm{O}$ group, is a core component of photosynthetic inhibitory activity $[224,247,248]$. TeA can induce a chloroplast-derived ROS burst that causes a range of irreversible cell damage, including chlorophyll degradation, lipid peroxidation, plasma membrane rupture, chromatin condensation, DNA cleavage, and organelle disinfection, eventually leading to rapid cell destruction and leaf necrosis in host plants [248]. TeA can also trigger the EXECUTER (EX) protein-dependent ${ }^{1} \mathrm{O}_{2}$ pathway leading to cell death in Arabidopsis seedlings [249]. A recent study suggests that cell death triggered by TeA is an essential requirement for the pathogen A. alternata to successfully infect host plants. Production of ROS was critical for pathogen invasion, proliferation, and disease symptom formation during infection. TeA significantly increased the ability of the pathogen to undergo invasive hyphal growth and spread [250].

Most tetramic acids are naturally derived from hybrid PKS and nonribosomal peptide synthetases (NRPS) that come from polyketides and $\alpha$-amino acids $[224,251,252]$. Thus, TeA was also expected to be a product of a PKS-NRPS hybrid enzyme [224,253]. Previous experiments with radioactive precursors showed that $A$. tenuis first used L-isoleucine and two acetate molecules to synthesize $\mathrm{N}$-acetoacetyl-L-isoleucine. Subsequently, TeA was formed by the cyclization of N-acetoacetyl-L-isoleucine [133,216,224,254]. Recently, the TeA biosynthetic gene TAS1 was discovered from M. oryzae. TAS1 encodes the TeA biosynthetic enzyme TAS1, which is a NPRS-PKS hybrid protein consisting of a C (condensation)-A (adenylation)-PCP (peptidyl carrier protein)-KS (ketosynthase) domain structure [252,255]. It was found that the C-A-PCP domain of TAS1 condenses L-isoleucine and acetoacetyl-CoA to yield N-acetoacetyl-L-isoleucine, while the KS domain recognizes the $\mathrm{N}$-acetoacetylL-isoleucine hybrid to initiate the cyclization reaction to produce TeA [252,255]. In 2020, the mechanism of cyclization to form the tetramic acid ring was illustrated by the KS domain of TAS1 in the course of TeA biosynthesis. TAS1-KS contains a conserved catalytic triad Cys179-His322-Asn376. The substrate N-acetoacetyl-L-isoleucine was transferred from the PCP domain to Cys 179 via a thioester bond. The substrate was positioned by a hydrogen bond to Ser 324, and then the methylene proton was abstracted by His-322, which triggered a nucleophilic attack on the thioester carbonyl to give TeA. Asn376 could stabilize the conformation of cis-N-acetoacetyl-L-isoleusin for the nucleophilic attack to form TeA $[252,256]$.

Much like the above biosynthetic pathway of TeA, the addition of L-isoleucine could stimulate the production of 3-acetyl-5-isopropyltetramic acid and 3-acetyl-5-isobutyltetramic acid. In this biosynthetic pattern, it is possible and useful to obtain tetramic acids with different side chains at the 5-position by growing the organism in media fed with different L-amino acids. Gatenbeck and co-workers added ${ }^{14} \mathrm{C}$-carboxyl-labeled L-valine or L-leucine to the culture media of $A$. tenuis. From the culture extracts, the 5-isopropyl and the 5-isobutyl derivatives of the tetramic acids were prepared and purified, i.e., 3acetyl-5-isopropyltetramic acid (3-AIPTA) and 3-acetyl-5-isobutyltetramic acid (iso-TeA, Figure 9) [133].

Based on a bioassay, 3-AIPTA showed phytotoxicity to a wide range of plants. It inhibited the root and shoot length of seedlings and eventually killed seedlings of both monocotyledonous and dicotyledonous weeds. 3-AIPTA was able to inhibit PSII electron 
transport rates and the growth of algal cells [257]. Further studies indicated that 3-AIPTA had the same target and lethal mechanism as TeA on weeds, but the herbicidal effect was much weaker compared to TeA [258].

3-Acetyl-5-isobutyltetramic acid, also called iso-tenuazonic acid (iso-TeA), was an isomer of TeA. Because of its similar chemical structure to TeA (Figure 9), the two toxins were thought to have similar toxicological relevance. Iso-TeA showed remarkable toxic effects on Artemia salina, with a mortality rate of $68.9 \%$ compared to $73.6 \%$ for TeA [259]. Iso-TeA also showed antibacterial effect on B. megaterium [230]. It also showed significant phytotoxicity, such as the inhibition of rice root growth with an $\mathrm{ID}_{50}(50 \%$ inhibitory dose) of $0.28 \mathrm{mM}$ and marked browning of rice leaves at $10 \mathrm{mM}$ [260].

\subsection{Cyclic Peptides}

Cyclic peptides exhibit remarkable biological activities due to their condensed structures [261]. In this section, we have introduced tentoxin and its competing derivatives, all of which belong to this family.

Tentoxin (TEN, Figure 10) is a secondary metabolite produced by several Alternaria species, including A. alternata, A. citri, A. longipes, A. mali, A. porri, and A. tenuis [134-139]. Based on the analysis of the acidic hydrolysis products and spectroscopic properties of the compound, it was found that tentoxin is a cyclic tetrapeptide containing glycine, L-leucine, $\mathrm{N}$ methyl-L-alanine, and N-methy-L-dehydrphenylalany. The complete structure of tentoxin is cy-clo[ $N$-methyl-L-alanyl-L-leucyl-(Z)- $\alpha, \beta$-dehydro- $N$-methylphenylalanylglycyl] $[262,263]$. In addition to tentoxin, dihydrotentoxin (DHT) and isotentoxin (isoTEN) have also been isolated as metabolites from Alternaria species [253]. Tentoxin can be found in many products, including wheat, sorghum, fruit, and barley [264,265]. Therefore, the EFSA applied the toxicological threshold of concern (TTC) approach to TEN in its preliminary risk assessment, which was set at $1500 \mathrm{ng} \cdot \mathrm{kg}^{-1}$ body weight per day [180,263].



Tentoxin

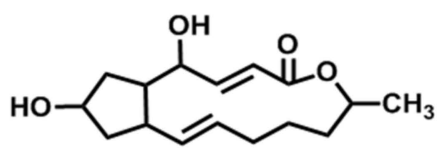

Brefeldin A

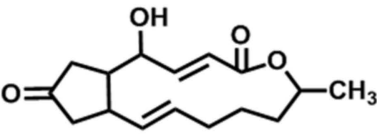

7-Dehydrobrefeldin A<smiles>COc1cccc(CC(=O)O[C@@H](C)C/C=C\C(=O)c2ccc(O)c(OC)c2O)c1</smiles>

Aldaulactone<smiles>COc1c(C)c(CO)cc(OCC=C(C)C)c1C</smiles>

Zinniol<smiles>CC(=O)Cc1cc(O)cc(O)c1</smiles>

$\alpha$-Acetylorcinol<smiles>O=C(O)c1ccc(O)cc1</smiles>

p-Hydroxybenzoic acid

Figure 10. Chemical structures of Alternaria NHSTs belonging to the cyclic peptide (Tentoxin) macrolides (Brefeldin A, 7-dehydrobrefeldin A, and aldaulactone) and phenolics (Zinniol, $a$ acetylorcinol, and $p$-hydroxybenzoic acid) families.

As a phytotoxin, tentoxin was found to induce chlorosis in germinating seedlings of some dicotyledonous plants, but not in maize, tomatoes, and members of the Brassicaceae and Poaceae families. This was explained by the fact that sensitive species might possess a specific receptor site for tentoxin, resulting in the selective disruption of chloroplast function, reduction in the levels of chloroplast-specific lipids and proteins, and ultrastructural changes in chloroplasts $[137,266,267]$. Further studies indicated that tentoxin is a specific, non-competitive inhibitor of photophosphorylation and the site of action is associated with chloroplast F1-ATPase (CF1) [268,269]. Interestingly, ATP hydrolysis and synthesis were inhibited at a low dose of tentoxin, while ATPase activity was stimulated at high 
concentrations [270]. In 2002, the crystal structure of CF1 in complex with tentoxin showed that the binding site was located in a cleft at the $\alpha \beta$-subunit [269]. Recently, the study of the cryo-EM structure of CF1 in complex with tentoxin indicated that the cyclic ring of tentoxin with the charged or polar residues ( $\beta$ Asp83, $\beta$ Thr82, $\alpha$ Arg297, and $\alpha$ Tyr271) and its isobutyl and phenyl moieties interact with the hydrophobic residues $(\alpha$ Ile63, $\alpha$ Leu65, and $\alpha$ Val75) between the $\alpha$ - and $\beta$-subunit, leading to a decrease in enzyme activity [271]. In addition, tentoxin also exhibits independent effects on plant metabolism, such as stomatal movements, ion uptake and translocation, and internal ion concentrations [272].

Previous studies indicated that tentoxin appeared on day 5 after inoculation with A. alternata, increased rapidly, and reached a maximum between days 9 and 12. After 14 days of inoculation, the synthesis decreased [273]. Methionine is the carbon donor in the biosynthesis of tentoxin and its precursor dihydrotentoxin [273,274]. In 1994, the tentoxin synthetase was isolated, which is a polyfunctional multienzyme with an integrated methyltransferase activity that contains active $\mathrm{SH}$ groups. The precursor amino acids were bound to the enzyme, then $\mathrm{N}$-methylation and peptide extension occurred. Finally, dihydrotentoxin was formed by cyclization and then released to be converted into tentoxin [273]. Some researchers reported that the NRPS gene $\mathrm{CmNps3}$ was responsible for tentoxin biosynthesis in C. miyabeanus, and predicted that the gene AaNps3 might be involved in tentoxin biosynthesis in Alternaria species [275]. Recently, two genes for tentoxin biosynthesis, a NPRS gene (TES) and a cytochrome P450 gene (TES1), were found in A. alternata [276]. TES encodes a protein of 5161 amino acids. TES1 was closely associated with TES in a $5^{\prime}$-end-to- $5^{\prime}$-end arrangement and was predicted to be involved in dehydrophenylalanine biosynthesis. Furthermore, a detailed analysis of TES revealed that it has a typical modular NRPS organization and consists of four modules with $\mathrm{N}$-methyltransferase domains in both the second and fourth modules. The arrangement of the domains is A-T-C-A-M-T-CA-T-C-A-M-T-C. TES assembles four precursor amino acids, Gly, Ala, Leu, and DPhe. The $\mathrm{N}$-methylation of Ala and DPhe occurred in the N-methyltransferase domains, respectively. The condensation domain was located in the termination module of TES, which is responsible for the formation of intramolecular macrocyclization and final tentoxin release [276]. These findings are helpful for further studies on NRPS proteins in fungi and the mechanism of DPhe biosynthesis.

\subsection{Macrolides}

Brefeldin A (BFA) and its analogues 7-dehydrobrefeldin A (7-oxo-BFA) belong to the macrolide family, which possess antibiotic properties (Figure 10). Previously, BFA was isolated from Penicillium species and later found in Alternaria spp. such as A. carthami and A. zinnia [140,141]. 7-Oxo-BFA is another macrolide that is a potent phytotoxin of A. carthami [141]. BFA was particularly active. It could cause the rapid appearance of large necrotic patches and a 70\% reduction in chlorophyll content when Xanthium occidentale leaves were treated with $10^{-4} \mathrm{M}$ BFA [141]. One $\mu \mathrm{g} \cdot \mathrm{mL}^{-1}$ BFA was sufficient to inhibit both the germination and growth of tobacco pollen tubes and also cause the collapse of Golgi stacks [277]. Further studies showed that the Golgi stacks were the common target of BFA and 7-oxo-BFA. 7-Oxo-BFA was a more potent destroyer of the Golgi stacks than BFA [278]. As a macrolide, BFA also exhibited other important bioactivities, including antifungal, cytostatic, antimitotic, antiviral, and anticancer activities [279,280]. In most mammalian cells, 1-10 $\mu \mathrm{g} \cdot \mathrm{mL}^{-1}$ BFA not only inhibited secretion [281,282], but also caused profound morphological changes, including the decay of the Golgi apparatus and redistribution of Golgi enzymes into the endoplasmic reticulum [278]. BFA showed high cytotoxicity against HL-60, KB, Hela, MCF-7, and Spc-A-1 cell lines $\left(\mathrm{IC}_{50}=1.0-10.0 \mathrm{ng} \cdot \mathrm{mL}^{-1}\right)$ [280]. There is no report on the biosynthetic pathway of BFA and 7-oxo-BFA so far.

Aldaulactone was a 10-membered benzenediol lactone molecule and was firstly purified from A. dauci, which was toxic to a large range of dicotyledonous plants, especially carrot. It was also indicated that aldaulactone was involved in both fungal pathogenicity and plant resistance mechanisms. In phytotoxicity, aldaulactone was toxic to carrot cells, 
inducing a delay in embryonic development and a decrease in cell viability [142]. The biological function and biosynthetic pathway of aldaulactone has not yet been defined.

\subsection{Phenols}

Zinniol (Figure 10), a member of the phenol family, was first isolated from A. zinnia (Starratt, 1968) and later detected in culture filtrates of A. dauci [143], A. tagetica [144], A. solani, A. porri, A. carthami, A. macrospora, and A. cichorii [145]. Zinniol showed a broad phytotoxic spectrum that could cause necrotic leaf damage [144,283,284]. Zinniol could act specifically on a certain class of plant calcium channels, but its target is not comparable to calcium channel blockers [285]. The two hydroxymethyl groups of zinniol are essential for its phytotoxic activity [143]. However, a few studies suggested that zinniol is not markedly phytotoxic to embryogenic cellular cultures of Daucus carota [286] and the leaves of Tagetes erecta [287] at physiological concentrations. In addition, Zinniol also showed cytotoxic activity in rat embryonic fibroblasts with an $\mathrm{IC}_{50}$ of $264 \mu \mathrm{g} \cdot \mathrm{mL}^{-1}$ [284]. In general, there is still much room for research for this potential natural product.

$\alpha$-Acetylorcinol is a resorcinol derivative that was first isolated from C. lunata in 1977 [288], and has also been reported as a secondary metabolite from various Alternaria spp., including A. tenuissima, A. brassicicola, and A. dauci [146]. It exhibited phytotoxic activity in many plants. It can induce necrosis to Sida Spinosa, Chenopodium album, Ipomoea sp., Datura stramonium, Sorghum bicolor, S. halepense [289], and Nioctiana alata [146]. $\alpha$-Acetylorcinol also showed antifungal activity against Trichophyton rubrum and A. fumigatus [290].

There were many reports on the production of $p$-hydroxybenzoic acid by fungi, such as A. tagetica [147] and A. dauci [146]. It was also produced by Epichloë bromicola and Diaporthe gulyae, which were the phytopathogens of Elymus tangutorum and sunflower, respectively [291]. $p$-Hydroxybenzoic acid could inhibit the germination and root length of Rumex crispus [292]. Additionally, it also exhibited antibacterial [293], antioxidant [294], antifungal [295], antialgal [296], antimutagenic [297], and estrogenic activity [298].

\section{Summary and Outlook}

Alternaria is a ubiquitous genus in many ecosystems, consisting of saprophytic, pathogenic, and even endophytic species. Thus, they are a rich source of secondary metabolites. The production of various HSTs and NHSTs can be considered as a crucial reason for the survival of these fungi. In this review, we have listed only some parts of the toxins of the known Alternaria species. The great structural diversity, high potency, and exclusive mechanisms of action make these toxins extremely attractive for the discovery of their bioactivity. Many Alternaria toxins exhibit excellent herbicidal, antimicrobial, antitumor, and other bioactive properties. Some of them can be directly developed into drugs or pesticides, while others can serve as lead compounds for the discovery of new drugs or pesticides. However, several challenges must be overcome for their successful development as drug or pesticide candidates in the future. First, the biological activities and modes of action of most toxins are still unclear. Second, some active crude extracts need further purification to discover the exact active components. Third, the content of many toxins in Alternaria is low, so a deep exploration of their biosynthetic pathways is needed to increase the yield of the useful bioactive parts.

Author Contributions: Writing-original draft preparation, H.W., Y.G., Z.L., L.G., R.L. and Y.Z.; writing-review and editing, S.C., H.W., Y.G., H.M.K., Z.L. and S.Q. All authors have read and agreed to the published version of the manuscript.

Funding: This research was funded by Jiangsu Agriculture Science and Technology Innovation Fund (No. CX(21)3093) and the Postgraduate Research \& Practice Innovation Program of Jiangsu Province (No. KYCX19_0617).

Institutional Review Board Statement: This article does not contain any studies with human or animal subjects.

Informed Consent Statement: Not applicable. 
Data Availability Statement: All data presented in this study are contained in main text.

Acknowledgments: We thank Baojun $\mathrm{Xu}$, who invited us to submit a paper to this special issue.

Conflicts of Interest: The authors have declared no conflict of interest.

\section{References}

1. Thomma, B.P.H.J. Alternaria spp.: From general saprophyte to specific parasite. Mol. Plant Pathol. 2003, 4, 225-236. [CrossRef] [PubMed]

2. Lawrence, D.P.; Gannibal, P.B.; Peever, T.L.; Pryor, B.M. The sections of Alternaria: Formalizing species-group concepts. Mycologia 2013, 105, 530-546. [CrossRef] [PubMed]

3. Lee, H.B.; Patriarca, A.; Magan, N. Alternaria in food: Ecophysiology, mycotoxin production and toxicology. Mycobiology 2015, 43, 93-106. [CrossRef] [PubMed]

4. $\quad$ Woudenberg, J.H.C.; Seidl, M.F.; Groenewald, J.Z.; de Vries, M.; Stielow, J.B.; Thomma, B.P.H.J.; Crous, P.W. Alternaria section Alternaria: Species, formae speciales or pathotypes? Stud. Mycol. 2015, 82, 1-21. [CrossRef]

5. Zwickel, T.; Kahlm, S.; Rychlik, M.; Muller, M. Chemotaxonomy of mycotoxigenic small-spored Alternaria fungi-do multitoxin mixtures act as an indicator for species differentiation? Front. Microbiol. 2018, 9, 1368. [CrossRef] [PubMed]

6. Lou, J.; Fu, L.; Peng, Y.; Zhou, L. Metabolites from Alternaria fungi and their bioactivities. Molecules 2013, 18, 5891-5935. [CrossRef] [PubMed]

7. Takaoka, S.; Kurata, M.; Harimoto, Y.; Hatta, R.; Yamamoto, M.; Akimitsu, K.; Tsuge, T. Complex regulation of secondary metabolism controlling pathogenicity in the phytopathogenic fungus Alternaria alternata. New Phytol. 2014, 202, 1297-1309. [CrossRef]

8. Howlett, B.J. Secondary metabolite toxins and nutrition of plant pathogenic fungi. Curr. Opin. Plant Biol. 2006, 9, 371-375. [CrossRef]

9. Tsuge, T.; Harimoto, Y.; Akimitsu, K.; Kodama, M.; Akagi, Y.; Egusa, M.; Yamamoto, M.; Otani, H. Host-selective toxins produced by the plant pathogenic fungus Alternaria alternata. FEMS Microbiol. Rev. 2013, 37, 44-66. [CrossRef]

10. Nakashima, T.; Ueno, T.; Fukami, H.; Taga, T.; Masuda, H.; Osaki, K.; Otani, H.; Kohmoto, K.; Nishimura, S. Isolation and structure of AK-toxin I and II, host specific phytotoxic metabolites produced by Alternaria alternata Japanese pear pathotype. Agric. Biol. Chem. 1985, 49, 807-815. [CrossRef]

11. Nakatsuka, S.; Ueda, K.; Goto, T.; Yamamoto, M.; Nishimura, S.; Kohmoto, K. Structure of AF-toxin II, one of the host-specific toxins produced by Alternaria alternata strawberry pathotype. Tetrahedron Lett. 1986, 27, 2753-2756. [CrossRef]

12. Mikihiro, Y.; Fumio, N.; Syoyo, N.; Keisuke, K. Studies on host-specific AF-toxins produced by Alternaria alternata strawberry pathotype causing Alternaria black spot of strawberry (3) Use of toxin for determining inheritance of disease reaction in strawberry cultivar morioka-16. Ann. Phytopath. Soc. Jpn. 1985, 51, 530-535.

13. Pegg, K.G. Studies of strain of Alternaria citri pierce, the causal organism of brown spot of Emperor mandarn. Queensl. J. Agric. Anim. Sci. 1966, 23, 15-28.

14. Timmer, L.W.; Solel, Z.; Orozco-Santos, M. Alternaria brown spot of mandarins. In Compendium of Citrus Diseases, 2nd ed.; Timmer, L.W., Garnsey, S.M., Graham, J.H., Eds.; Amer Phytopathological Society: Saint Paul, MI, USA, 2000; pp. 19-21.

15. Akimitsu, K.; Peever, T.L.; Timmer, L.W. Molecular, ecological and evolutionary approaches to understanding Alternaria diseases of citrus. Mol. Plant Pathol. 2003, 4, 435-446. [CrossRef]

16. Grogan, R.; Kimble, K.; Misaghi, I. A stem canker disease of tomato caused by Alternaria alternata f. sp. lycopersici. Phytopathology 1975, 65, 880-886. [CrossRef]

17. Gilchrist, D.G. Production and nature of a host-specific toxin from Alternaria alternata f. sp. lycopersici. Phytopathology 1976, 66, 165-171. [CrossRef]

18. Kohmoto, K.; Scheffer, R.; Whiteside, J. Host-Selective Toxins from Alternaria citri. Phytopathology 1979, 69, 667-671. [CrossRef]

19. Kohmoto, K.; Akimitsu, K.; Otani, H. Correlation of resistance and susceptibility of citrus to Alternaria alternata with sensitivity to host-specific toxins. Phytopathology 1991, 81, 719-722. [CrossRef]

20. Okuno, T.; Ishita, Y.; Sawai, K.; Matsumoto, T. Characterization of alternariolide, a host-specific toxin produced by Alternaria mali Roberts. Chem. Lett. 1974, 3, 635-638. [CrossRef]

21. Hoffmeister, D.; Keller, N. Natural products of filamentous fungi: Enzymes, genes, and their regulation. Nat. Prod. Rep. 2007, 24, 393-416. [CrossRef]

22. Tewari, J.; Bains, P. Phytotoxins produced by Alternaria brassicae and bioassay of destruxin B. In Toxins in Plant Disease Development and Evolving Biotechnology; Upadhyay, R., Ed.; Science Publishers: Enfield, NH, USA, 1997; Volume 2, pp. 21-35.

23. Parada, R.Y.; Sakuno, E.; Mori, N.; Oka, K.; Egusa, M.; Kodama, M.; Otani, H. Alternaria brassicae produces a host-specific protein toxin from germinating spores on host leaves. Biochem. Cell Biol. 2008, 98, 458-463. [CrossRef] [PubMed]

24. Pringle, R.B. Amino acid composition of the host-specific toxin of Helminthosporium carbonum. Plant Physiol. 1971, 48, 756-759. [CrossRef]

25. Kawai, M.; Rich, D.H.; Walton, J.D. The structure and conformation of HC-toxin. Biochem. Biophys. Res. Comm. 1983, 111, 398-403. [CrossRef] 
26. Wight, W.D.; Labuda, R.; Walton, J.D. Conservation of the genes for HC-toxin biosynthesis in Alternaria jesenskae. BMC Microbiol. 2013, 13, 165. [CrossRef] [PubMed]

27. Harris, P.; Cranston, R. An economic evaluation of control methods for diffuse and spotted knapweed in Western Canada. Can. J. Plant Sci. 1979, 59, 375-382. [CrossRef]

28. Bobylev, M.M.; Bobyleva, L.I.; Strobel, G.A. Synthesis and bioactivity of analogs of maculosin, a host-specific phytotoxin produced by Alternaria alternata on spotted knapweed (Centaurea maculosa). J. Agric. Food Chem. 1996, 44, 3960-3964. [CrossRef]

29. Liakopoulou-Kyriakides, M.; Lagopodi, A.L.; Thanassoulopoulos, C.C.; Stavropoulos, G.S.; Magafa, V. Isolation and synthesis of a host-selective toxin produced by Alternaria alternate. Phytochemistry 1997, 45, 37-40. [CrossRef]

30. Feng, B.; Nakastuka, S.; Goto, T.; Tsuge, T.; Nishimura, S. Biosyntheses of host-selective toxins produced by Alternaria alternata pathogens, I: $(8 R, 9 S)-9,10$-epoxy-8-hydroxy-9-methyl-deca-(2E, 4Z, 6E)-trienoic acid as a biological precursor of AK-toxins. Agric. Biol. Chem. 1990, 54, 845-848. [CrossRef]

31. Gardner, J.M.; Kono, Y.; Tatum, J.H.; Suzuki, Y.; Takeuchi, S. Structure of the major component of ACRL-toxins, host-specific pathotoxic compound produced by Alternaria citri. Agric. Biol. Chem. 1985, 49, 1235-1238. [CrossRef]

32. Foyer, C.H.; Noctor, G. Redox sensing and signalling associated with reactive oxygen in chloroplasts, peroxisomes and mitochondria. Physiol. Plant. 2003, 119, 355-364. [CrossRef]

33. Namiki, F.; Yamamoto, M.; Nishimura, S.; Nakatsuka, S.; Goto, T.; Kohmot, K.; Otani, H. Studies on host-specific AF-toxins produced by Alternaria alternata strawberry pathotype causing Alternaria black spot of strawberry. 4. Protective effect of AF-toxin II on AF-toxin I-induced toxic action and fungal infection. Ann. Phytopath. Soc. Jpn. 1986, 52, 428-436. [CrossRef]

34. Maekawa, N.; Yamamoto, M.; Nishimura, S.; Kohmoto, K.; Kuwada, K.; Watanabe, Y. Studies on host-specific AF-toxins produced by Alternaria alternata strawberry pathotype causing Alternaria black spot of strawberry. (1) Production of host-specific toxins and their biological activities. Ann. Phytopathol Soc. Jpn. 1984, 50, 600-609. [CrossRef]

35. Kohmoto, K.; Itoh, Y.; Shimomura, N.; Kondoh, Y.; Otani, H.; Kodama, M.; Nishimura, S.; Nakatsuka, S. Isolation and biological activities of two host-specific toxins from the tangerine pathotype of Alternaria alternata. Phytopathology 1993, 83, 495-502. [CrossRef]

36. Otani, H.; Kohmoto, K.; Nishimura, S.; Nakashima, T.; Ueno, T.; Fukami, H. Biological activities of AK-toxins I and II, host-specific toxins from Alternaria alternata Japanese pear pathotype. Ann. Phytopathol Soc. Jpn. 1985, 51, 285-293. [CrossRef]

37. Park, P.; Ikeda, K. Ultrastructural analysis of responses of host and fungal cells during plant infection. J. Gen. Plant Pathol. 2008, 74, 2-14. [CrossRef]

38. Meena, M.; Samal, S. Alternaria host-specific (HSTs) toxins: An overview of chemical characterization, target sites, regulation and their toxic effects. Toxicol. Rep. 2019, 6, 745-758. [CrossRef] [PubMed]

39. Namiki, F.; Okamoto, H.; Katou, K.; Yamamoto, M.; Nishimura, S.; Nakatsuka, S.; Goto, T.; Kohmoto, K.; Otani, H.; Novacky, A Studies on host-specific toxins produced by Alternaria alternata strawberry pathotype causing Alternaria black spot of strawberry (5) Effect of toxins on membrane potential of susceptible plants by means of electrophysiological analysis. Ann. Phytopathol. Soc. Jpn. 1986, 52, 610-619. [CrossRef]

40. Otani, H.; Tomiyama, K.; Okamoto, H.; Nishimura, S.; Kohmoto, K. Effect of AK-toxin produced by Alternaria alternata Japanese pear pathotype on membrane potential of pear cells. Ann. Phytopathol. Soc. Jpn. 1989, 55, 466-468. [CrossRef]

41. Otani, H.; Kohmoto, K.; Kodama, M.; Nishimura, S. Role of host-specific toxins in the pathogenesis of Alternaria alternata. In Molecular Strategies of Pathogens and Host Plants; Patil, S.S., Ouchi, S., Mills, D., Vance, C., Eds.; Springer: Berlin, Germany, 1991; Volume 3, pp. 139-149.

42. Otani, H.; Kohmoto, K.; Kodama, M. Alternaria toxins and their effects on host plants. Can. J. Bot. 1995, 73, 453-458. [CrossRef]

43. Uemura, I.; Miyagawa, H.; Ueno, T. Asymmetric total synthesis of AK-toxins. Terahedron 2002, 58, 2351-2358. [CrossRef]

44. Morita, Y.; Hyon, G.; Hosogi, N.; Miyata, N.; Nakayashiki, H.; Muranaka, Y.; Inada, N.; Park, P.; Ikeda, K. Appressorium-localized NADPH oxidase B is essential for aggressiveness and pathogenicity in the host-specific, toxin-producing fungus Japanese Alternaria alternata pear pathotype. Mol. Plant Path. 2013, 4, 365-378. [CrossRef] [PubMed]

45. Wu, P.; Chen, C.; Choo, C.; Chen, Y.; Yago, J.; Chung, K. Proper functions of peroxisomes are vital for pathogenesis of Citrus brown spot disease caused by Alternaria alternata. J. Fungi 2020, 6, 248. [CrossRef] [PubMed]

46. Nakatsuka, S.; Feng, B.; Goto, T.; Tsuge, T.; Nishiumra, S. Biosynthesis of host-selective toxins produced by Alternaria alternata pathogens. 2. Biosynthetic origin of (8R,9S)-9,10-epoxy-8-hydroxy-9-methyl-deca-(2E,4Z,6E)-trienoic acid, a precursor of AKtoxins produced by Alternaria alternata. Phytochemistry 1990, 29, 1529-1531. [CrossRef]

47. Tanaka, A.; Shiotani, H.; Yamamoto, M.; Tsuge, T. Insertional mutagenesis and cloning of the genes required for biosynthesis of the hostspecific AK-toxin in the Japanese pear pathotype of Alternaria alternata. Mol. Plant-Microbe Interact. 1999, 12, 691-702. [CrossRef]

48. Tanaka, A.; Tsuge, T. Structural and functional complexity of the genomic region controlling AK-toxin biosynthesis and pathogenicity in the Japanese pear pathotype of Alternaria alternata. Mol. Plant-Microbe Interact. 2000, 13, 975-986. [CrossRef]

49. Hatta, R.; Ito, K.; Hosaki, Y.; Tanaka, T.; Tanaka, A.; Yamamoto, M.; Akimitsu, K.; Tsuge, T. A conditionally dispensable chromosome controls host-specific pathogenicity in the fungal plant pathogen Alternaria alternata. Genetics 2002, 161, 59-70. [CrossRef] [PubMed]

50. Masunaka, A.; Tanaka, A.; Tsuge, T.; Peever, T.L.; Timmer, L.W.; Yamamoto, M.; Yamamoto, H.; Akimitsu, K. Distribution and characterization of AKT homologs in the tangerine. Phytopathology 2000, 90, 762-768. [CrossRef] [PubMed] 
51. Masunaka, A.; Ohtani, K.; Peever, T.; Timmer, L.; Tsuge, T.; Yamamoto, M.; Yamamoto, H.; Akimitsu, K. An isolate that is pathogenic to both tangerines and rough lemon and produces two host-selective toxins, ACT- and ACR-toxins. Phytopathology 2005, 95, 241-247. [CrossRef] [PubMed]

52. Miyamoto, Y.; Masunaka, A.; Tsuge, T.; Yamamoto, M.; Ohtani, K.; Fukumoto, T.; Gomi, K.; Peever, T.; Akimitsu, K. Functional analysis of a multicopy host-selective ACT-toxin biosynthesis gene in the tangerine pathotype of Alternaria alternata using RNA silencing. Mol. Plant-Microbe Interact. 2008, 21, 1591-1599. [CrossRef] [PubMed]

53. Imazaki, A.; Tanaka, A.; Harimoto, Y.; Yamamoto, M.; Akimitsu, K.; Park, P.; Tsuge, T. Contribution of peroxisomes to secondary metabolism and pathogenicity in the fungal plant pathogen Alternaria alternata. Eukaryot. Cell 2010, 9, 682-694. [CrossRef]

54. Li, L.; Ma, H.; Zheng, F.; Chen, Y.; Wang, M.; Jiao, C.; Li, H.; Gai, Y. The transcription regulator ACTR controls ACT-toxin biosynthesis and pathogenicity in the tangerine pathotype of Alternaria alternata. Microbiol. Res. 2021, 248, 126747. [CrossRef] [PubMed]

55. Covert, S.F. Supernumerary chromosomes in filamentous fungi. Curr. Genet. 1998, 33, 311-319. [CrossRef] [PubMed]

56. Ito, K.; Tanaka, T.; Hatta, R.; Yamamoto, M.; Akimitsu, K.; Tsuge, T. Dissection of the host range of the fungal plant pathogen Alternaria alternata by modification of secondary metabolism. Mol. Microbiol. 2004, 52, 399-411. [CrossRef] [PubMed]

57. Miyamoto, Y.; Isshiki, Y.; Honda, A.; Masunaka, A.; Tsuge, T.; Yamamoto, M.; Ohtani, K.; Fukumoto, T.; Gomi, K.; Peever, T.; et al. Function of genes encoding acyl-CoA synthetase and enoyl-CoA hydratase for host-selective ACT-toxin biosynthesis in the tangerine pathotype of Alternaria alternata. Phytopathology 2009, 99, 369-377. [CrossRef] [PubMed]

58. Sugahara, S.; Ito, Y.; Sakurai, Y.; Narikawa, T.; Sakata, Y. Varietal difference of the resistance to stem canker caused by Alternaria alternata in tomato. Res. Bull. Aichi Agric. Res. Cent. 1989, 21, 170-175.

59. Bottini, A.; Gilchrist, D.; Phytotoxins, I. A 1-aminodimethylheptadecapentol from Alternaria alternata f. sp. lycopersici. Tetrahedron Lett. 1981, 22, 2719-2722. [CrossRef]

60. Bottini, A.T.; Bowen, J.R.; Gilchrist, D.G. Phytotoxins. II. Characterization of a phytotoxic fraction from Alternaria alternata f. sp. lycopersici. Tetrahedron Lett. 1981, 22, 2723-2726. [CrossRef]

61. Brandwagt, B.F.; Mesbah, L.A.; Takken, F.L.W.; Laurent, P.L.; Kneppers, T.J.A.; Hille, J.; Nijkamp, H.J.J. A longevity assurance gene homolog of tomato mediates resistance to Alternaria alternata f. sp. lycopersici toxins and fumonisin B1. Proc. Natl. Acad. Sci. USA 2000, 97, 4961-4966. [CrossRef]

62. Caldas, E.D.; Jones, A.D.; Ward, B.; Winter, C.K.; Gilchrist, D.G. Structural characterization of three new AAL-toxins produced by Alternaria alternata f. sp. lycopersici. J. Agric. Food Chem. 1994, 42, 327-333. [CrossRef]

63. Abbas, H.K.; Duke, S.O.; Paul, R.N.; Riley, R.T.; Tanaka, T. AAL-toxin, a potent natural herbicide which disrupts sphingolipid metabolism of plants. Pestic. Sci. 1995, 43, 181-187. [CrossRef]

64. Mesbah, L.A.; Van Der Weerden, G.M.; Nijkamp, H.J.J.; Hille, J. Sensitivity among species of Solanaceae to AAL toxins produced by Alternaria alternata f.sp. lycopersici. Plant Pathol. 2000, 49, 734-741. [CrossRef]

65. Duke, S.O.; Dayan, F.E. Modes of action of microbially-produced phytotoxins. Toxins 2011, 3, 1038-1064. [CrossRef] [PubMed]

66. Shier, W.T.; Abbas, H.K.; Mirocha, C.J. Toxicity of the mycotoxins fumonisins B1 and B2 and Alternaria alternata f. sp. lycopersici toxin (AAL) in cultured mammalian cells. Mycopathologia 1991, 116, 97-104. [CrossRef] [PubMed]

67. Van Bruggen, A.H.C.; He, M.M.; Shin, K.; Mai, V.; Jeong, K.C.; Finckh, M.R.; Morris, J.G. Environmental and health effects of the herbicide glyphosate. Sci. Total Environ. 2018, 616, 255-268. [CrossRef]

68. Abbas, H.K.; Tanaka, T.; Shier, W.T. Biological activities of synthetic analogues of Alternaria alternata toxin (AAL-toxin) and fumonisin in plant and mammalian cell cultures. Phytochemistry 1995, 40, 1681-1689. [CrossRef]

69. Duke, S.O.; Dayan, F.E. Clues to new herbicide mechanisms of action from natural sources. ACS Sym. Ser. 2013, 1141, $203-215$.

70. Gilchrist, D.G. Mycotoxins reveal connections between plants and animals in apoptosis and ceramide signaling. Cell Death Differ. 1997, 4, 1312-1317. [CrossRef] [PubMed]

71. Orolaza, N.; Kawakita, K.; Doke, N. Inhibitory effect of AL-toxin produced by Alternaria alternata tomato pathotype on the biosynthesis of phosphatidylethanolamine in tomato leaves susceptible to the fungus. Ann. Phytopath. Soc. Jpn. 1992, 58, 719-725. [CrossRef]

72. Shi, L.; Bielawski, J.; Mu, J.; Dong, H.; Teng, C.; Zhang, J.; Yang, X.; Tomishige, N.; Hanada, K.; Hannun, Y.A.; et al. Involvement of sphingoid bases in mediating reactive oxygen intermediate production and programmed cell death in Arabidopsis. Cell Res. 2007, 17, 1030-1040. [CrossRef]

73. Shao, Z.; Zhao, Y.; Liu, L.; Chen, S.; Li, C.; Meng, F.; Liu, H.; Hu, S.; Wang, J.; Wang, Q. Overexpression of FBR41 enhances resistance to sphinganine analog mycotoxin-induced cell death and Alternaria stem canker in tomato. Plant Biotechnol. J. 2020, 18, 141-154. [CrossRef]

74. Abbas, H.K.; Tanaka, T.; Duke, S.O.; Porter, J.K.; Wray, E.M.; Hodges, L.; Sessions, A.E.; Wang, E.; Merrill, A.H.; Riley, A.R.T. Fumonisin-induced and AAL-toxin-induced disruption of sphingolipid metabolism with accumulation of free sphingoid gases. Plant Physiol. 1994, 106, 1085-1093. [CrossRef]

75. Markham, J.E.; Hille, J. Host-selective toxins as agents of cell death in plant-fungus interactions. Mol. Plant Pathol. 2001, 1, 229-239. [CrossRef]

76. Zhang, L.; Jia, C.; Liu, L.; Li, C.; Wang, Q. Involvement of jasmonates and ethylene in Alternaria alternata f. sp. lycopersici toxin-induced tomato cell death. J. Exp. Bot. 2011, 15, 5405-5418. [CrossRef]

77. Ismaiel, A.; Papenbrock, J. Mycotoxins: Producing fungi and mechanisms of phytotoxicity. Agriculture 2015, 5, 492-537. [CrossRef] 
78. Caldas, E.D.; Sadilkova, K.; Ward, B.L.; Jones, A.D.; Winter, C.K.; Gilchrist, D.G. Biosynthetic studies of fumonisin B-1 and AAL toxins. J. Agric. Food Chem. 1998, 46, 4734-4743. [CrossRef]

79. Doidge, E. A study of some Alternarias infecting citrus in South Africa. S. Afr. Dept Agric. Sci. Bull. 1929, 69, 99-112.

80. Nishimura, S.; Tatano, S.; Miyamoto, Y.; Ohtani, K.; Fukumoto, T.; Gomi, K.; Tada, Y.; Ichimura, K.; Akimitsu, K. A zinc-binding citrus protein metallothionein can act as a plant defense factor by controlling host-selective ACR-toxin production. Plant Mol. Biol. 2013, 81, 1-11. [CrossRef]

81. Nishimura, S.; Kohmoto, K. Host-specific toxins and chemical structures from Alternaria species. Annu. Rev. Phytopathol. 1983, 21, 87-116. [CrossRef]

82. Akimitsu, K.; Kohmoto, K.; Otani, H.; Nishimura, S. Host-specific effect of toxin from the rough lemon pathotype of Alternaria alternata on mitochondria. Plant Physiol. 1989, 89, 925-931. [CrossRef]

83. Ohtani, K.; Yamamoto, H.; Akimitsu, K. Sensitivity to Alternaria alternata toxin in citrus because of altered mitochondrial RNA processing. Proc. Natl. Acad. Sci. USA 2002, 99, 2439-2444. [CrossRef] [PubMed]

84. Izumi, Y.; Kamei, E.; Miyamoto, Y.; Ohtani, K.; Masunaka, A.; Fukumoto, T.; Gomi, K.; Tada, Y.; Ichimura, K.; Peever, T.; et al. Role of the pathotype-specific ACRTS1 gene encoding a hydroxylase involved in the biosynthesis of host-selective ACR-toxin in the rough lemon pathotype of Alternaria alternata. Phytopathology 2012, 102, 741-748. [CrossRef]

85. Izumi, Y.; Ohtani, K.; Miyamoto, Y.; Masunaka, A.; Fukumoto, T.; Gomi, K.; Tada, Y.; Ichimura, K.; Peever, T.; Akimitsu, K. A polyketide synthase gene, ACRTS2, is responsible for biosynthesis of host-selective ACR-toxin in the rough lemon pathotype of Alternaria alternata. Mol. Plant-Microbe Interact. 2012, 25, 1419-1429. [CrossRef] [PubMed]

86. Akimitsu, K.; Ohtani, K.; Shimagami, T.; Katsumoto, M.; Igarashi, C.; Tanaka, S.; Matsuoka, S.; Mochizuki, S.; Tsuge, T.; Yamamoto, M.; et al. Citrus as a molecular contact point for co-evolution of Alternaria pathogens. Physiol. Mol. Plant Pathol. 2016, 95, 93-96. [CrossRef]

87. Ueno, T.; Nakashima, T.; Uemota, M.; Fukami, H.; Lee, S.; Izumiya, N. Mass spectrometry of Alternaria mali toxins and related cyclodepsipeptides. Biol. Mass Spectrom. 1977, 4, 134-142. [CrossRef] [PubMed]

88. Park, P.; Nishimura, S.; Kohmoto, K.; Otani, H.; Tsujimoto, K. Two action sites of AM-toxin I produced by apple pathotype of Alternaria alternate in host cell: An ultrastructural study. Can. J. Bot. 1981, 59, 301-310. [CrossRef]

89. Kohmoto, K.; Otani, H. Host recognition by toxigenic plant-pathogens. Experientia 1991, 47, 755-764. [CrossRef]

90. Li, Y.; Aldwinckle, H.; Sutton, T.; Tsuge, T.; Kang, G.; Cong, P.; Cheng, G. Interactions of apple and the Alternaria alternata apple pathotype. Crit. Rev. Plant Sci. 2013, 32, 141-150. [CrossRef]

91. Keller, N.; Turner, G.; Bennett, J. Fungal secondary metabolism-biochemistry to genomics. Nat. Rev. Microbiol. 2005, 3, 937-947. [CrossRef]

92. Johnson, R.D.; Johnson, L.; Itoh, Y.; Kodama, M.; Otani, H.; Kohmoto, K. Cloning and characterization of a cyclic peptide synthetase gene from Alternaria alternata apple pathotype whose product is involved in AM-toxin synthesis and pathogenicity. Mol. Plant-Microbe Interact. 2000, 13, 742-753. [CrossRef]

93. Harimoto, Y.; Tanaka, T.; Kodama, M.; Yamamoto, M.; Otani, H.; Tsuge, T. Multiple copies of AMT2 are prerequisite for the apple pathotype of Alternaria alternata to produce enough AM-toxin for expressing pathogenicity. J. Gen. Plant Pathol. 2008, 74, 222-229. [CrossRef]

94. Harimoto, Y.; Hatta, R.; Kodama, M.; Yamamoto, M.; Otani, H.; Tsuge, T. Expression profiles of genes encoded by the supernumerary chromosome controlling AM-toxin biosynthesis and pathogenicity in the apple pathotype of Alternaria alternata. Mol. Plant-Microbe Interact. 2007, 20, 1463-1476. [CrossRef] [PubMed]

95. Bains, P.S.; Tewari, J.P. Purification, chemical characterization and host-specificity of the toxin produced by Alternaria-Brassicae Physiol. Mol. Plant Pathol. 1987, 30, 259-271. [CrossRef]

96. Buchwaldt, L.; Green, H. Phytotoxicity of destruxin B and its possible role in the pathogenesis of Alternaria brassicae. Plant Pathol. 1992, 41, 55-63. [CrossRef]

97. Pedras, M.S.; Zaharia, I.; Gai, Y.; Zhou, Y.; Ward, D. In planta sequential hydroxylation and glycosylation of a fungal phytotoxin: Avoiding cell death and overcoming the fungal invader. Proc. Natl. Acad. Sci. USA 2001, 98, 747-752. [CrossRef] [PubMed]

98. Morel, E.; Païs, M.; Turpin, M.; Guyot, M. Cytotoxicity of cyclodepsipeptides on murine lymphocytes and on L 1210 leukemia cells. Biomed. Pharmacother. 1983, 37, 184-185. [PubMed]

99. Sun, C.; Chen, H.; Yeh, S. Suppressive effects of metabolites from Alternaria brassicae on the hepatitis B surface antigen. Planta Med. 1994, 60, 87-88. [CrossRef] [PubMed]

100. Chen, H.; Chou, C.; Sun, C.; Yeh, S. Suppressive effects of destruxin B on hepatitis B virus surface antigen gene expression in human hepatoma cells. Antivir. Res. 1997, 34, 137-144. [CrossRef]

101. Bandani, A.R.; Amiri, B.; Butt, T.M.; Gordon-Weeks, R. Effects of efrapeptin and destruxin, metabolites of entomogenous fungi, on the hydrolytic activity of a vacuolar type ATPase identified on the brush border membrane vesicles of Galleria mellonella midgut and on plant membrane bound hydrolytic enzymes. Biochim. Biophys. Acta 2001, 1510, 367-377. [CrossRef]

102. Suzuki, A.; Tamura, S. Isolation and structure of protodestruxin from Metarrhizium anisopliae. Agric. Biol. Chem. 1972, 36, 896-898. [CrossRef]

103. Jegorov, A.; Sedmera, P.; Matha, V. Biosynthesis of destruxins. Phytochemistry 1993, 33, 1403-1405. [CrossRef]

104. Ullstrup, A.J. Inheritance of susceptibility to infection by Helminthosporium maydis race 1 in maize. J. Agric. Res. 1941, 63, 331-334. 
105. Kim, S.D.; Knoche, H.W.; Dunkle, L.D.; Mccrery, D.A.; Tomer, K.B. Structure of an amino acid analogue of the host-specific toxin from Helminthosporium carbonum. Tetrahedron Lett. 1985, 26, 969-972. [CrossRef]

106. Walton, J.D. Host-selective toxins: Agents of compatibility. Plant Cell 1996, 8, 1723-1733.

107. Pitkin, J.W.; Nikolskaya, A.; Ahn, J.H.; Walton, J.D. Reduced virulence caused by meiotic instability of the TOX2 chromosome of the maize pathogen Cochliobolus carbonum. Mol. Plant-Microbe Interact. 2000, 13, 80-87. [CrossRef]

108. Stierle, A.C.; Cardellina, J.H.; Strobel, G.A. Maculosin, a host-specific phytotoxin for spotted knapweed from Alternaria alternata. Proc. Natl. Acad. Sci. USA 1988, 85, 8008-8013. [CrossRef]

109. Park, S.H.; Strobel, G.A. Cellular protein receptors of maculosin, a host-specific phytotoxin of spotted knapweed (Centaurea maculosa L.). Biochim. Biophys. Acta-Gen. Subj. 1994, 1199, 11-19. [CrossRef]

110. Lopes, S.C.D.N.; Fedorova, A.; Castanho, M.A.R.B. Cholesterol modulates maculosin's orientation in model systems of biological membranes relevance towards putative molecular recognition. Steroids 2004, 69, 825-830. [CrossRef]

111. Paudel, B.; Maharjan, R.; Rajbhandarib, P.; Aryalc, N.; Azizc, S.; Bhattaraic, K.; Barald, B.; Malla, R.; Bhattarai, H. Maculosin, a non-toxic antioxidant compound isolated from Streptomyces sp. KTM18. Pharm. Biol. 2021, 59, 933-936. [CrossRef]

112. Robeson, D.J.; Gray, G.R.; Strobel, G.A. Production of the phytotoxins radicinin and radicinol by Alternaria chrysanthemi. Phytochemistry 1982, 21, 2359-2362. [CrossRef]

113. Sheridan, H.; Canning, A.M. Novel radicinol derivatives from long-term cultures of Alternaria chrysanthemi. J. Nat. Prod. 1999, 62, 1568-1569. [CrossRef]

114. Tal, B.; Robeson, D.J.; Burke, B.A.; Aasen, A.J. Phytotoxins from Alternara helianthi and the structures of deoxyradicinol and radianthin. Phytochemistry 1985, 24, 729-731. [CrossRef]

115. Tal, B.; Robeson, D.J. The production of pyrenocines A and B by a novel Alternaria species. Z. Naturforsch. C 1986, 41, 11-12. [CrossRef]

116. Ichihara, A.; Tazaki, H.; Sakamura, S. Solanapyrones A, B and C, phytotoxic metabolites from the fungus Alternaria solani. Tetrahedron Lett. 1983, 24, 5373-5376. [CrossRef]

117. Wang, X.; Luo, X.; Xiao, J.; Zhai, M.; Yuan, Y.; Zhu, Y.; Crews, P.; Yuan, C.; Wu, Q. Pyrone derivatives from the endophytic fungus Alternaria tenuissima SP-07 of Chinese herbal medicine Salvia przewalskii. Fitoterapia 2014, 99, 184-190. [CrossRef] [PubMed]

118. Pero, R.W.; Owens, R.G.; Dale, S.W.; Harvan, D. Isolation and identification of a new toxin, altenuene, from the fungus Alternaria tenuis. Biochim. Biophys. Acta 1971, 230, 170-179. [CrossRef]

119. Pero, R.W.; Posner, H.; Blois, M.; Harvan, D.; Spalding, J.W. Toxicity of metabolites produced by the "Alternaria". Environ. Health Perspect. 1973, 4, 87-94. [CrossRef]

120. Okuno, T.; Natsume, I.; Sawai, K.; Sawamura, K.; Furusaki, A.; Matsumoto, T. Structure of antifungal and phytotoxic pigments produced by Alternaria sps. Tetrahedron Lett. 1983, 24, 5653-5656. [CrossRef]

121. Wu, W.; Yue, G.; Huang, Q.; Sun, L.; Zhang, W. A new compound from an endophytic fungus Alternaria tenuissima. J. Asian Nat. Prod. Res. 2014, 16, 777-782. [CrossRef] [PubMed]

122. Bashyal, B.P.; Wellensiek, B.P.; Ramakrishnan, R.; Faeth, S.H.; Ahmad, N.; Gunatilaka, A.A.L. Altertoxins with potent anti-HIV activity from Alternaria tenuissima QUE1Se, a fungal endophyte of Quercus emoryi. Bioorg. Med. Chem. 2014, 22, 6112-6116. [CrossRef]

123. Kong, F.; Yi, T.; Ma, Q.; Xie, Q.; Zhou, L.; Chen, J.; Dai, H.; Wu, Y.; Zhao, Y. Biphenyl metabolites from the patchouli endophytic fungus Alternaria sp. PfuH1. Fitoterapia 2020, 146, 104708. [CrossRef]

124. Stierle, A.C.; Cardellina, J.H.; Strobel, G.A. Phytotoxins from Alternara alternata, a pathogen of spotted knapweed. J. Nat. Prod. 1989, 52, 42-47. [CrossRef]

125. Stack, M.E.; Mazzola, E.P. Stemphyltoxin III from Alternaria alternata. J. Nat. Prod. 1989, 52, 426-427. [CrossRef] [PubMed]

126. Stoessl, A. Some metabolites of Alternaria solani. Can. J. Chem. 1969, 47, 767-776. [CrossRef]

127. Yagi, A.; Okamura, N.; Haraguchi, H.; Abo, T.; Hashimoto, K. Antimicrobial tetrahydroanthraquinones from a strain of Alternaria solani. Phytochemistry 1993, 33, 87-91. [CrossRef]

128. Charudattan, R.; Rao, K.V. Bostrycin and 4-deoxybostrycin: Two nonspecific phytotoxins produced by Alternaria eichhorniae. Appl. Environ. Microbiol. 1982, 43, 846-849. [CrossRef]

129. Suemitsu, R.; Iwai, J.; Kawaguchi, K.; Haitani, N.; Kitagawa, N. Isolation and identification of erythroglaucin (1, 4, 5-trihydroxy-7methoxy-2-methylanthraquinone) from the mycelium of Alternaria porri (Ellis) Ciferri. Agric. Biol. Chem. 1977, 41, 2289-2290.

130. Huang, C.; Pan, J.; Chen, B.; Yu, M.; Huang, H.; Zhu, X.; Lu, Y.; She, Z.; Lin, Y. Three bianthraquinone derivatives from the mangrove endophytic fungus Alternaria sp ZJ9-6B from the South China Sea. Mar. Drugs 2011, 9, 832-843. [CrossRef]

131. Chen, B.; Shen, Q.; Xun Zhu, X.; Lin, Y. The Anthraquinone derivatives from the fungus Alternaria sp. XZSBG-1 from the Saline Lake in Bange, Tibet, China. Molecules 2014, 19, 16529-16542. [CrossRef]

132. Ostry, V. Alternaria mycotoxins: An overview of chemical characterization, producers, toxicity, analysis and occurrence in foodstuffs. World Mycotoxin J. 2008, 1, 175-188. [CrossRef]

133. Gatenbeck, S.; Sierankiewicz, J. Microbial production of tenuazonic acid analogues. Antimicrob. Agents Chemother. 1973, 3, 308-309. [CrossRef] [PubMed]

134. Saad, S.M.; Halloin, J.M.; Hagedorn, D.J. Production, purification, and bioassay of tentoxin. Phytopathology 1970, 60, 415-418. [CrossRef] [PubMed] 
135. Liebermann, B.; Oertel, B. Bildung und isolierung des phytotoxins tentoxin aus Alternaria alternata. J. Basic Microbiol. 1983, 23, 503-511. [CrossRef]

136. Kono, Y.; Gardner, J.M.; Takeuchi, S. Nonselective phytotoxins simultaneously produced with hostselective ACTG-toxins by a pathotype of Alternaria citri causing brown spot. Agric. Biol. Chem. 1986, 50, 2401-2403.

137. Edwards, J.V.; Lax, A.R.; Lillehoj, E.B.; Boudreaux, G.J. Structure-activity relationships of cyclic and acyclic analogues of the phytotoxic peptide tentoxin. J. Agric. Food Chem. 1987, 35, 451-456. [CrossRef]

138. Suemitsu, R.; Sano, T.; Yamamoto, M.; Arimoto, Y.; Morimatsu, F.; Nabeshima, T. Structural elucidation of alterporriol B, a novel metabolic pigment produced by Alternaria porri (Ellis) ciferri. Agric. Biol. Chem. 1984, 48, 2611-2613. [CrossRef]

139. Duke, S.O. Tentoxin effects on variable fluorescence and P515 electrochromic absorbance changes in tentoxin-sensitive and -resistant plant. Plant Sci. 1993, 90, 119-126. [CrossRef]

140. Tietjen, K.G.; Matern, U. Induction and suppression of phytoalexin biosynthesis in cultured cells of safflower, Carthamus tinctorius L.; by metabolites of Alternaria carthami Chowdhury. Arch. Bioch. Biophy. 1984, 229, 136-144. [CrossRef]

141. Vurro, M.; Evidente, A.; Andolfi, A.; Zonno, M.C.; Giordano, F.; Motta, A. Brefeldin A and $\alpha$, $\beta$-dehydrocurvularin, two phytotoxins from Alternaria zinniae, a biocontrol agent of Xanthium occidentale. Plant Sci. 1998, 138, 67-79. [CrossRef]

142. Courtial, J.; Hamama, L.; Helesbeux, J.J.; Lecomte, M.; Renaux, Y.; Guichard, E.; Voisine, L.; Yovanopoulos, C.; Hamon, B.; Oge, L.; et al. Aldaulactone-an original phytotoxic secondary metabolite involved in the aggressiveness of Alternaria dauci on carrot. Front. Plant Sci. 2018, 9, 502. [CrossRef]

143. Barasch, I.; Mor, H.; Netzer, D.; Kashman, Y. Production of zinniol by Alternaria dauci and its phytotoxic effect on carrot. Physiol. Plant Pathol. 1981, 19, 7-16. [CrossRef]

144. Cotty, P.; Mishagi, I.; Hine, R. Production of zinniol by Alternaria tagetica and its phytotoxic effect on Tagetes erecta. Phytopathology 1983, 73, 1326-1328. [CrossRef]

145. Cotty, P.; Mishagi, I. Zinniol production by Alternaria species. Phytopathology 1984, 74, 785-788. [CrossRef]

146. Leyte-Lugo, M.; Richomme, P.; Poupard, P.; Pena-Rodriguez, L.M. Identification and quantification of a phytotoxic metabolite from Alternaria dauci. Molecules 2020, 25, 4003. [CrossRef]

147. Gamboa-Angulo, M.M.; García-Sosa, K.; Alejos-González, F.; Escalante-Erosa, F.; Delgado-Lamas, G.; Peña-Rodríguez, L.M. Tagetolone and tagetenolone: Two phytotoxic polyketides from Alternaria tagetica. J. Agric. Food Chem. 2001, 49, 1228-1232. [CrossRef] [PubMed]

148. Avula, S.K.; Das, B.; Csuk, R.; Al-Rawahi, A.; Al-Harrasi, A. Recent advances in the stereoselective total synthesis of natural pyranones having long side chains. Molecules 2020, 25, 1905. [CrossRef] [PubMed]

149. Clarke, D.D.; Nord, F.F. Radicinin: A new pigment from Stemphylium radicinum. Arch. Biochem. Biophys. 1953, 45, 469-470. [CrossRef]

150. Sato, H.; Konoma, K.; Sakamura, S. Phytotoxins produced by onion pink root jungus, Pyrenochaeta terrestris. Agric. Biol. Chem. 1979, 43, 2409-7506.

151. Masi, M.; Freda, F.; Clement, S.; Cimmino, A.; Cristofaro, M.; Meyer, S.; Evidente, A. Phytotoxic activity and structure-activity relationships of radicinin derivatives against the invasive weed buffelgrass (Cenchrus ciliaris). Molecules 2019, 24, 2793. [CrossRef] [PubMed]

152. Nakajima, H.; Ishida, T.; Otsuka, Y.; Hamasaki, T.; Ichinoe, M. Phytotoxins and related metabolites produced by Bipolaris coicis, the pathogen of Job's tears. Phytochemistry 1997, 45, 41-45. [CrossRef]

153. Solfrizzo, M.; Vitti, C.; Girolamo, A.D.; Visconti, A.; Logrieco, A.; Fanizzi, F.P. Radicinols and radicinin phytotoxins produced by Alternaria radicina on carrots. J. Agric. Food Chem. 2004, 52, 3655-3660. [CrossRef]

154. Santoro, E.; Mazzeo, G.; Marsico, G.; Masi, M.; Longhi, G.; Superchi, S.; Evidente, A.; Abbate, S. Assignment through chiroptical methods of the absolute configuration of fungal dihydropyranpyran-4-5-diones phytotoxins, potential herbicides for buffelgrass (Cenchrus ciliaris) biocontrol. Molecules 2019, 24, 3022. [CrossRef] [PubMed]

155. Giridharan, P.; Verekar, S.A.; Gohil, A.R.; Mishra, P.D.; Khanna, A.; Deshmukh, S.K. Antiproliferative activity of hamigerone and radicinol isolated from Bipolaris papendorfii. Biomed Res. Int. 2014, 2014, 890904. [CrossRef] [PubMed]

156. Kim, J.C.; Choi, G.J.; Kim, H.T.; Kim, H.J.; Cho, K.Y. Pathogenicity and pyrenocine production of Curvularia inaequalis isolated from zoysia grass. Plant Dis. 2000, 84, 684-688. [CrossRef] [PubMed]

157. Myobatake, Y.; Kamisuki, S.; Tsukuda, S.; Higashi, T.; Chinen, T.; Takemoto, K.; Hachisuka, M.; Suzuki, Y.; Takei, M.; Tsurukawa Y.; et al. Pyrenocine A induces monopolar spindle formation and suppresses proliferation of cancer cells. Bioorg. Med. Chem. 2019, 27, 115-149. [CrossRef]

158. Shishido, T.; Hachisuka, M.; Ryuzaki, K.; Miura, Y.; Tanabe, A.; Tamura, Y.; Kusayanagi, T.; Takeuchi, T.; Kamisuki, S.; Sugawara, F.; et al. EpsinR, a target for pyrenocine B, role in endogenous MHC-II-restricted antigen presentation. Eur. J. Immunol. 2014, 44, 3220-3231. [CrossRef]

159. Hamid, K.; Strange, R.N. Phytotoxicity of solanapyrones A and B produced by the chickpea pathogen Ascochyta rabiei (Pass.) Labr. and the apparent metabolism of solanapyrone A by chickpea tissues. Physiol. Mol. Plant Pathol. 2000, 56, 235-244. [CrossRef]

160. Mizushina, Y.; Kamisuki, S.; Kasai, N.; Shimazaki, N.; Takemura, M.; Asahara, H.; Linn, S.; Yoshida, S.; Matsukage, A.; Koiwai, O.; et al. A plant phytotoxin, solanapyrone A, is an inhibitor of DNA polymerase $\beta$ and $\lambda$. J. Biol. Chem. 2002, 277, 630-638. [CrossRef] [PubMed] 
161. Oikawa, H.; Yokota, T.; Sakano, C.; Suzuki, Y.; NaYa, A.; Ichihara, A. Solanapyrones. Phytotoxins produced by Alternaria solani: Biosynthesis and isolation of minor components. Biosci. Biotenchnol. Biochem. 1998, 62, 2016-2022. [CrossRef]

162. Kasahara, K.; Miyamoto, T.; Fujimoto, T.; Oguri, H.; Tokiwano, T.; Oikawa, H.; Tokiwano, T.; Oikawa, H.; Ebizuka, Y.; Fujii, I Solanapyrone synthase, a possible Diels-Alderase and iterative type I polyketide synthase encoded in a biosynthetic gene cluster from Alternaria solani. ChemBioChem 2010, 11, 1245-1252. [CrossRef] [PubMed]

163. Kim, W.; Park, C.M.; Park, J.J.; Akamatsu, H.O.; Peever, T.L.; Xian, M.; Gang, D.; Vandemark, G.; Chen, W. Functional analyses of the Diels-Alderase gene sol5 of Ascochyta rabiei and Alternaria solani indicate that the solanapyrone phytotoxins are not required for pathogenicity. Mol. Plant-Microbe Interact. 2015, 28, 482-496. [CrossRef]

164. Pan, L.; Dong, J.; Xie, D.; Li, Y.F.; Liu, Q. Synthesis of 2-(Trifluoromethyl)-dibenzopyranones with Rhodium(III)-catalyzed Formal anti-Michael Addition as Key Step. Adv. Synth. Catal. 2018, 360, 958-964. [CrossRef]

165. Raistrick, H.; Stickings, C.E.; Thomas, R. Studies in the biochemistry of microorganisms. 90. Alternariol and alternariol monomethyl ether, metabolic products of Alternaria tenuis. Biochem. J. 1953, 55, 421. [CrossRef] [PubMed]

166. Scott, P.M. Analysis of agricultural commodities and foods for Alternaria mycotoxins. J. Aoac. Int. 2001, 84, 1809-1817. [CrossRef] [PubMed]

167. Gruber-Dorninger, C.; Novak, B.; Nagl, V.; Berthiller, F. Emerging mycotoxins: Beyond traditionally determined food contaminants. J. Agric. Food Chem. 2017, 65, 7052-7070. [CrossRef] [PubMed]

168. Schade, J.; King, A. Analysis of the major Alternaria toxins. J. Food Product. 1984, 47, 978-995. [CrossRef]

169. Wollenhaupt, K.; Schneider, F.; Tiemann, U. Influence of alternariol (AOH) on regulator proteins of cap-dependent translation in porcine endometrial cells. Toxicol. Lett. 2008, 182, 57-62. [CrossRef] [PubMed]

170. Fehr, M.; Pahlke, G.; Fritz, J.; Christensen, M.O.; Boege, F.; Altemoller, M.; Podlech, J.; Marko, D. Alternariol acts as a topoisomerase poison, preferentially affecting the II $\alpha$ isoform. Mol. Nutr. Food Res. 2009, 53, 441-451. [CrossRef]

171. Solhaug, A.; Vine, L.L.; Ivanova, L.; Spilsberg, B.; Holme, J.A.; Pestka, J.; Collins, A.; Eriksen, G.S. Mechanisms involved in alternariol-induced cell cycle arrest. Mutat. Res.-Fund. Mol. Mutagen. 2012, 738, 1-11. [CrossRef] [PubMed]

172. Fernandez-Blanco, C.; Juan-Garcia, A.; Juan, C.; Font, G.; Ruiz, M.J. Alternariol induce toxicity via cell death and mitochondrial damage on Caco-2 cells. Food Chem. Toxicol. 2016, 88, 32-39. [CrossRef]

173. Vila-Donat, P.; Fernández-Blanco, C.; Sagratini, G.; Font, G.; Ruiz, M.J. Effects of soyasaponin I and soyasaponins-rich extract on the alternariol-induced cytotoxicity on Caco-2 cells. Food Chem. Toxicol. 2015, 77, 44-49. [CrossRef] [PubMed]

174. Bensassi, F.; Gallerne, C.; el Dein, O.S.; Hajlaoui, M.R.; Bacha, H.; Lemaire, C. Cell death induced by the Alternaria mycotoxin alternariol. Toxicol. In Vitro 2012, 26, 915-923. [CrossRef]

175. Fleck, S.; Burkhardt, B.; Pfeiffer, E.; Metzler, M. Alternaria toxins: Altertoxin II is a much stronger mutagen and DNA strand breaking mycotoxin than alternariol and its methyl ether in cultured mammalian cells. Toxicol. Lett. 2012, 214, 27-32. [CrossRef] [PubMed]

176. Solhaug, A.; Torgersen, M.; Holme, J.; Lagadic-Gossmann, D.; Eriksen, G. Autophagy and senescence, stress responses induced by the DNA-damaging mycotoxin alternariol. Toxicology 2014, 326, 119-129. [CrossRef]

177. Solhaug, A.; Wisbech, C.; Christoffersen, T.E.; Hult, L.O.; Lea, T.; Eriksen, G.S.; Holme, J.A. The mycotoxin alternariol induces DNA damage and modify macrophage phenotype and inflammatory responses. Toxicol. Lett. 2015, 239, 9-21. [CrossRef] [PubMed]

178. Liu, G.; Qian, Y.; Zhang, P.; Dong, W.; Qi, Y.; Guo, H. Etiological role of Alternaria alternata in human esophageal cancer. Chin Med. J. 1992, 105, 394-400.

179. An, Y.; Zhao, T.; Miao, J.; Liu, G.; Zheng, Y.; Xu, Y.; Van Etten, R.L. Isolation, identification, and mutagenicity of alternariol monomethyl ether. J. Agric. Food Chem. 1989, 37, 1341-1343. [CrossRef]

180. European Food Safety Authority. Panel on Contaminants in the Food Chain. Scientific opinion on the risks for animal and public health related to the presence of Alternaria toxins in feed and food. EFSA J. 2011, 9, 2407-2504. [CrossRef]

181. Siegel, D.; Feist, M.; Proske, M.; Koch, M.; Nehls, I. Degradation of the Alternaria mycotoxins alternariol, alternariol monomethyl ether, and altenuene upon bread baking. J. Agric. Food Chem. 2010, 58, 9622-9630. [CrossRef]

182. Xiao, J.; Zhang, Q.; Gao, Y.; Tang, J.; Zhang, A.; Gao, J. Secondary metabolites from the endophytic botryosphaeria dothiadea of melia azedarach and their antifungal, antibacterial, antioxidant, and cytotoxic activities. J. Agric. Food Chem. 2014, 62, 3584-3590. [CrossRef]

183. De Souza, G.D.; Mithofer, A.; Daolio, C.; Schneider, B.; Rodrigues-Filho, E. Identification of Alternaria alternata mycotoxins by LC-SPE-NMR and their cytotoxic effects to soybean (Glycine max) cell suspension culture. Molecules 2013, 18, 2528-2538 [CrossRef]

184. Tang, J.; Huang, L.; Liu, Y.; Toshmatov, Z.; Zhang, C.; Shao, H. Two phytotoxins isolated from the pathogenic fungus of the invasive weed Xanthium italicum. Chem. Biodivers. 2020, 7, e2000043. [CrossRef] [PubMed]

185. Demuner, A.J.; Barbosa, L.C.; Miranda, A.C.M.; Geraldo, G.C.; da Silva, C.M.; Giberti, S.; Bertazzini, M.; Forlani, G. The fungal phytotoxin alternariol 9-methyl ether and some of its synthetic analogues inhibit the photosynthetic electron transport chain. $J$. Nat. Prod. 2013, 76, 2234-2245. [CrossRef] [PubMed]

186. Thomas, R. Studies in the biosynthesis of fungal metabolites. Biochem. J. 1961, 80, 234-240. [CrossRef]

187. Gatenbeck, S.; Hermodsson, S. Enzymic synthesis of the aromatic product alternariol. Acta Chem. Scand. 1965, 19, 65-71. [CrossRef] 
188. Hiltunen, M.; Söderhäll, K. Alternariol-O-methyltransferase from Alternaria alternata: Partial purification and relation to polyketide synthesis. Exp. Mycol. 1992, 16, 44-51. [CrossRef]

189. Wenderoth, M.; Garganese, F.; Schmidt-Heydt, M.; Soukup, S.T.; Ippolito, A.; Sanzani, S.M.; Fischer, R. Alternariol as virulence and colonization factor of Alternaria alternata during plant infection. Mol. Microbiol. 2019, 1, 131-146. [CrossRef]

190. Kumagai, Y.; Shinkai, Y.; Miura, T.; Cho, A.K. The chemical biology of naphthoquinones and its environmental implications. Annu. Rev. Pharmacol. Toxicol. 2012, 52, 221-247. [CrossRef]

191. Hu, J.; Sarrami, F.; Li, H.; Zhang, G.; Stubbs, K.; Lacey, E.; Stewart, S.; Karton, A.; Piggott, A.; Chooi, Y. Heterologous biosynthesis of elsinochrome A sheds light on the formation of the photosensitive perylenequinone system. Chem. Sci. 2019, 10, 1457-1465. [CrossRef]

192. Stack, M.E.; Mazzola, E.P.; Page, S.W.; Pohland, A.E.; Highet, R.J.; Tempesta, M.S.; Corley, D.G. Mutagenic perylenequinone metabolites of Alternaria alternata: Altertoxins I, II, and III. J. Nat. Prod. 1986, 49, 866-871. [CrossRef]

193. Stack, M.E.; Prival, M.J. Mutagenicity of the Alternaria metabolites altertoxins-I, altertoxins-II, and altertoxins-III. Appl. Environ. Microbiol. 1986, 52, 718-722. [CrossRef]

194. Fleck, S.C.; Sauter, F.; Pfeiffer, E.; Metzler, M.; Hartwig, A.; Köberle, B. DNA damage and repair kinetics of the Alternaria mycotoxins alternariol, altertoxin II and stemphyltoxin III in cultured cells. Mutat. Res. Genet. Toxicol. Environ. Mutagen. 2016, 798-799, 27-34. [CrossRef]

195. Zhang, N.; Zhang, C.; Xiao, X.; Zhang, Q.; Huang, B. New cytotoxic compounds of endophytic fungus Alternaria sp. isolated from Broussonetia papyrifera (L.) Vent. Fitoterapia 2016, 110, 173-180. [CrossRef] [PubMed]

196. Robeson, D.; Strobel, G.; Matusumoto, G.K.; Fisher, E.L.; Chen, M.; Clardy, J. Alteichin: An unusual phytotoxin from Alternaria eichorniae, a fungal pathogen of water hyacinth. Experientia 1984, 40, 1248-1250. [CrossRef] [PubMed]

197. Hradil, C.M.; Hallock, Y.F.; Clardy, J.; Kenfield, D.S.; Strobel, G. Phytotoxins from Alternaria cassia. Phytochemistry 1989, 28 , 73-75. [CrossRef]

198. Davis, V.M.; Stack, M.E. Mutagenicity of stemphylotoxin-III, A metabolite of Alternaria alternata. Appl. Environ. Microbiol. 1991, 57, 180-182. [CrossRef] [PubMed]

199. Malik, E.M.; Muller, C.E. Anthraquinones as pharmacological tools and drugs. Med. Res. Rev. 2016, 36, 705-748. [CrossRef]

200. Okamura, N.; Mimura, K.; Yagi, A. Altersolanol-related compounds from the culture liquid of Alternaria solani. Phytochemistry 1996, 42, 77-80. [CrossRef]

201. Suemitsu, R.; Yamadaa, Y.; Sanoa, T.; Yamashitaa, K. Phytotoxic ativities of Altersolanol A, B and dactylariol, and activities of altersolanol A against Some microorganisms. Agric. Biol. Chem. 1984, 48, 2383-2384.

202. Haraguchi, H.; Abo, T.; Fukuda, A.; Okamura, N.; Yagi, A. Mode of phytotoxic action of altersolanols. Phytochemistry 1996, 43, 989-992. [CrossRef]

203. Evidente, A.; Rodeva, R.; Andolfi, A.; Stoyanova, Z.; Perrone, C.; Motta, A. Phytotoxic polyketides produced by Phomopsis foeniculi, a strain isolated from diseased Bulgarian fennel. Eur. J. Plant Pathol. 2011, 130, 173-182. [CrossRef]

204. Mishra, P.D.; Verekar, S.A.; Deshmukh, S.K.; Joshi, K.S.; Fiebig, H.H.; Kelter, G. Altersolanol A: A selective cytotoxic anthraquinone from a Phomopsis sp. Lett. Appl. Microbiol. 2015, 60, 387-391. [CrossRef] [PubMed]

205. Trigos, A.; Mendoza, G.; Espinoza, C.; Salinas, A.; Fernandez, J.J.; Norte, M. The role of macrosporin in necrotic spots. Phytochem. Lett. 2011, 4, 122-125. [CrossRef]

206. Yuan, P.; He, L.; Chen, D.; Sun, Y.; Ge, Z.; Shen, D.; Lu, Y. Proteomic characterization of Mycobacterium tuberculosis reveals potential targets of bostrycin. J. Proteom. 2020, 212, 103576. [CrossRef] [PubMed]

207. Lin, W.; Fang, L.; Liu, J.; Cheng, W.; Yun, M.; Yang, H. Inhibitory effects of marine fungal metabolites from the South China Sea on prostate cancer cell line DU-145. Int. J. Intern. Med. 2008, 35, 562-564.

208. Chen, W.; Hou, J.; Guo, Y.; Yang, H.; Xie, C.; Lin, Y.; She, Z. Bostrycin inhibits proliferation of human lung carcinoma A549 cells via downregulation of the PI3K/Akt pathway. J. Exp. Clin. Cancer Res. 2011, 30, 17. [CrossRef]

209. Jie, J.; Shi, L.; Yue, S.; Wang, M.; Zhang, J. Bostrycin inhibits growth of tongue squamous cell carcinoma cells by inducing mitochondrial apoptosis. Transl. Cancer Res. 2020, 9, 3926-3936. [CrossRef]

210. Qin, X.; Peng, Y.; Zheng, J. In vitro and in vivo studies of the electrophilicity of physcion and its oxidative metabolites. Chem. Res. Toxicol. 2018, 31, 340-349. [CrossRef]

211. Mueller, S.O.; Schmitt, M.; Dekant, W.; Stopper, H.; Schlatter, J.; Lutz, W.K. Occurrence of emodin, chrysophanol and physcion in vegetables, herbs and liquors. Genotoxicity and anti-genotoxicity of the anthraquinones and of the whole plants. Food Chem. Toxicol. 1999, 37, 481-491. [CrossRef]

212. Anke, H.; Kolthoum, I.; Laatsch, H. Metabolic products of microorganisms. 192. The anthraquinones of the Aspergillus glaucus group. II. Biological activity. Arch. Microbiol. 1980, 126, 231-236. [CrossRef] [PubMed]

213. Wang, S.; Li, X.; Teuscher, F.; Li, D.; Diesel, A.; Ebel, R.; Proksch, P.; Wang, B. Chaetopyranin, a benzaldehyde derivative, and other related metabolites from Chaetomium globosum, an endophytic fungus derived from the marine red alga Polysiphonia urceolata. J. Nat. Prod. 2006, 69, 1622-1625. [CrossRef]

214. Ohnishi, K.; Tanabe, H.; Hayashi, S.; Suemitsu, R. Biosynthesis of Alterporriol-A by Alternara porri. Biosci. Biotechnol. Biochem. 1992, 56, 42-43. [CrossRef]

215. Kang, S.; Pandey, R.; Lee, C.; Sim, J.; Jeong, J.; Choi, B.; Jung, M.; Ginzburg, D.; Zhao, K.; Won, S.; et al. Genome-enabled discovery of anthraquinone biosynthesis in Senna tora. Nat. Commun. 2020, 11, 5875. [CrossRef] [PubMed] 
216. Royles, B.J.L. Naturally occurring tetramic acids: Structure, isolation, and synthesis. Chem. Rev. 1995, 95, 1981-2001. [CrossRef]

217. Rosett, T.; Sankhala, R.H.; Stickings, C.E.; Taylor, M.E.U.; Thomas, R. Studies in the biochemistry of microorganisms. Metabolites of Alternaria tenuis auct: Culture filtrate products. Biochem. J. 1957, 67, 390-400. [CrossRef]

218. Kumari, A.; Singh, K. Evaluation of prophylactic efficacy of cinnamaldehyde in murine model against Paradendryphiella arenariae mycotoxin tenuazonic acid-induced oxidative stress and organ toxicity. Sci. Rep. 2021, 11, 19420. [CrossRef]

219. Stickings, C.E. Studies in the biochemistry of micro-organisms. 106. Metabolites of Alternaria tenuis auct.: The structure of tenuazonic acid. Biochem. J. 1959, 72, 332-340. [CrossRef]

220. Iwasaki, S.; Muro, H.; Nozoe, S.; Okuda, S.; Sato, Z. Isolation of 3,4-dihydro-3,4,8-trihydroxy-2(2H)-naphthalenone and tenuazonic acid from Pyricularia oryzae Cavara. Tetrahedron Lett. 1972, 1, 13-16. [CrossRef]

221. Steyn, P.S.; Rabie, C.J. Characterization of magnesium and calcium tenuazonate from Phoma sorghina. Phytochemistry 1976, 15, 1977-1979. [CrossRef]

222. Montemurro, N.; Visconti, A. Alternaria metabolites-chemical and biological data. In Alternaria Biology, Plant Diseases and Metabolites; Chelkowski, J., Visconti, A., Eds.; Elsevier Science: Amsterdam, The Netherlands; London, UK; New York, NY, USA; Tokyo, Japan, 1992; pp. 449-541.

223. Ebbole, D. Magnaporthe as a model for understanding host-pathogen interactions. Annu. Rev. Phytopathol. 2007, 45, 437-456. [CrossRef]

224. Chen, S.; Qiang, S. Recent advances in tenuazonic acid as a potential herbicide. Pestic. Biochem. Phys. 2017, $143,252-257$. [CrossRef]

225. Siegel, D.; Rasenko, T.; Koch, M.; Nehls, I. Determination of the Alternaria mycotoxin tenuazonic acid in cereals by highperformance liquid chromatography-electrospray ionization ion-trap multistage mass spectrometry after derivatization with 2 , 4-dinitrophenylhydrazine. J. Chromatogr. A 2009, 1216, 4582-4588. [CrossRef] [PubMed]

226. Gross, M.; Curtui, V.; Ackermann, Y.; Latif, H.; Usleber, E. Enzyme immunoassay for tenuazonic acid in apple and tomato products. J. Agric. Food Chem. 2011, 59, 12317-12322. [CrossRef]

227. Motoyama, T. Secondary metabolites of the rice blast fungus Pyricularia oryzae: Biosynthesis and biological function. Int. J. Mol. Sci. 2020, 21, 8698. [CrossRef]

228. Miller, F.; Rightel, W.; Sloan, B.; Ehrlich, J.; French, J.; Bartz, Q.; Dixon, G. Antivial activity of tenuazonic acid. Nature 1963, 2000, 1338-1339. [CrossRef] [PubMed]

229. Kaczka, E.A.; Gitterman, C.O.; Dulaney, E.L.; Smith, M.C.; Hendlin, D.; Woodruff, H.; Folkers, K. Discovery of inhibitory activity of tenuazonic acid for growth of human adenocarcinoma-1. Biochem. Biophys. Res. Commun. 1964, 14, 54-57. [CrossRef]

230. Gitterman, C.O. Antitumor, cytotoxic, and antibacterial activities of tenuazonic acid and congeneric tetramic acids. J. Med. Chem. 1965, 8, 483-486. [CrossRef] [PubMed]

231. Zhao, H.; Cui, Z.; Gu, Y.; Liu, Y.; Wang, Q. The phytotoxicity of natural tetramic acid derivatives. Pest Manag. Sci. 2011, 67, 1059-1061. [CrossRef]

232. Smith, E.R.; Fredrickson, T.N.; Hadidian, Z. Toxic effects of the sodium and the $N, N^{\prime}$-dibenzylethylenediamine salts of tenuazonic acid. Cancer Chemother. Rep. 1968, 52, 579-585.

233. Davies, N.D.; Diner, U.L.; Morgan-Jones, G. Tenuazonic acid production by Alternaria alternata and Alternaria tenuissima isolated from cotton. Appl. Environ. Microbiol. 1977, 34, 155-157. [CrossRef] [PubMed]

234. Shigeura, H.T.; Gordon, C.N. The biological activity of tenuazonic acid. Biochemistry 1963, 2, 1132-1137. [CrossRef]

235. Asam, S.; Rychlik, M. Potential health hazards due to the occurrence of the mycotoxin tenuazonic acid in infant food. Eur. Food Res. Technol. 2013, 236, 491-497. [CrossRef]

236. Umetsu, M.; Chiba, S.; Ogawa, S.; Nakao, T. Immune responses in mycoplasma pneumoniae infections. Uirusu 1974, $24,157-163$. [CrossRef] [PubMed]

237. Meazza, G.; Scheffler, B.E.; Tellez, M.R.; Rimando, A.M.; Romagni, J.G.; Duke, S.O.; Nanayakkara, D.; Khan, I.A.; Abourashed, E.A.; Dayan, F.E. The inhibitory activity of natural products on plant $p$-hydroxyphenylpyruvate dioxygenase. Phytochemistry 2002, 59, 281-288. [CrossRef]

238. Bjork, P.K.; Rasmussen, S.A.; Gjetting, S.K.; Havshoi, N.W.; Petersen, T.I.; Ipsen, J.O.; Larsen, T.O.; Fuglsang, A.T. Tenuazonic acid from Stemphylium loti inhibits the plant plasma membrane $\mathrm{H}^{+}$-ATPase by a mechanism involving the C-terminal regulatory domain. New Phytol. 2020, 226, 770-784. [CrossRef] [PubMed]

239. Zonno, M.; Vurro, M. Effect of fungal toxins on germination of Striga hermonthica seeds. Weed Res. 1999, 39, 15-20. [CrossRef]

240. Marfori, E.C.; Kajiyama, S.I.; Fukusaki, E.I.; Kobayashi, A. Phytotoxicity of the tetramic acid metabolite trichosetin. Photochemistry 2003, 62, 715-721. [CrossRef]

241. Tylkowska, K.; Grabarkiewicz-Szczesna, J.; Iwanowska, H. Production of toxins by Alternaria alternata and A. radicina and their effects on germination of carrot seeds. Seed Sci. Technol. 2003, 31, 309-316. [CrossRef]

242. Zhou, B.; Qiang, S. Effect of tenuazonic acid produced by Alternaria alternata on mironucleus and karyokinesis of Vicia faba root tip cells. Chin. J. App. Environ. Biol. 2007, 13, 803-806.

243. Qiang, S.; Summerell, B.A.; Li, Y. Pathogenicity of Alternaria alternata on Crofton weed (Eupatorium adenophorum). In Proceedings of the 17th Asian-Pacific Weed Science Society Conference, Bangkok, Thailand, 22-27 November 1999; pp. 556-561. 
244. Qiang, S.; Wan, Z.; Dong, Y.; Li, Y. Phytotoxicity of crude metabolites produced by Alternaria alternata to Crofton weed. In Sustainable Management towards the 21 Century in China, Proceedings of the 6th Weed Science Conference of China, Nanning, China, 1 March 1999; Guangxi Nationality Press Nanning: Nanning, China, 1999.

245. Chen, S.; Dai, X.; Qiang, S.; Tang, Y. Effect of a nonhost-selective toxin from Alternaria alternata on chloroplast-electron transfer activity in Eupatorium adenophorum. Plant Pathol. 2005, 54, 671-677. [CrossRef]

246. Zhou, B.; Wang, H.; Meng, B.; Wei, R.; Wang, L.; An, C.; Chen, S.; Yang, C.; Qiang, S. An evaluation of tenuazonic acid, a potential biobased herbicide in cotton. Pest Manag. Sci. 2019, 75, 2482-2489. [CrossRef]

247. Chen, S.; Xu, X.; Dai, X.; Yang, C.; Qiang, S. Identification of tenuazonic acid as a novel type of natural photosystem II inhibitor binding in $\mathrm{Q}_{\mathrm{B}}$-site of Chlamydomonas reinhardtii. Biochim. Biophys. Acta 2007, 1767, 306-318. [CrossRef] [PubMed]

248. Chen, S.; Yin, C.; Qiang, S.; Zhou, F.; Dai, X. Chloroplastic oxidative burst induced by tenuazonic acid, a natural photosynthesis inhibitor, triggers cell necrosis in Eupatorium adenophorum Spreng. Biochim. Biophys. Acta 2010, 1797, 391-405. [CrossRef] [PubMed]

249. Chen, S.; Strasser, R.J.; Qiang, S. In vivo assessment of effect of phytotoxin tenuazonic acid on PSII reaction centers. Plant Physiol. Biochem. 2014, 84, 10-21. [CrossRef]

250. Shi, J.; Zhang, M.; Gao, L.; Yang, Q.; Kalaji, H.; Qiang, S.; Strasser, R.; Chen, S. Tenuazonic acid-triggered cell death is the essential prerequisite for Alternaria alternata (Fr.) Keissler to infect successfully host Ageratina adenophora. Cells 2021, 10, 1010. [CrossRef]

251. Schobert, R.; Schlenk, A. Tetramic and tetronic acids: An update on new derivatives and biological aspects. Bioorg. Med. Chem. 2008, 16, 4203-4221. [CrossRef]

252. Mo, X.; Gulder, T.A.M. Biosynthetic strategies for tetramic acid formation. Nat. Prod. Rep. 2020, 38, 1555-1566. [CrossRef]

253. Collemare, J.; Billard, A.; Böhnert, H.; Lebrun, M.H. Biosynthesis of secondary metabolites in the rice blast fungus Magnaporthe grisea: The role of hybrid PKS-NRPS in pathogenicity. Mycol. Res. 2008, 112, 207-2015. [CrossRef]

254. Stickings, C.; Townsend, R. Studies in the biochemistry of micro-organisms. 108. Metabolites of Alternaria tenuis Auct.: The biosynthesis of tenuazonic acid. Biochem. J. 1961, 78, 412-418. [CrossRef] [PubMed]

255. Yun, C.; Motoyama, T.; Osada, H. Biosynthesis of the mycotoxin tenuazonic acid by a fungal NRPS-PKS hybrid enzyme. Nat. Commun. 2015, 6, 8758. [CrossRef]

256. Yun, C.; Nishimoto, K.; Motoyama, T.; Shimizu, T.; Hino, T.; Dohmae, N.; Nagano, S.; Osada, H. Unique features of the ketosynthase domain in a nonribosomal peptide synthetase-polyketide synthase hybrid enzyme, tenuazonic acid synthetase $1 . J$. Biol. Chem. 2020, 295, 11602-11612. [CrossRef] [PubMed]

257. Chen, S.; Zhou, F.; Yin, C.; Strasser, R.; Yang, C.; Qiang, S. Application of fast chlorophyll a fluorescence kinetics to probe action target of 3-acetyl-5-isopropyltetramic acid. Environ. Exp. Bot. 2011, 71, 269-279. [CrossRef]

258. Chen, S.; Yin, C.; Strasser, R.; Govindjee; Yang, C.; Qiang, S. Reactive oxygen species from chloroplasts contribute to 3-acetyl5-isopropyltetramic acid-induced leaf necrosis of Arabidopsis thaliana. Plant Physiol. Biochem. 2012, 52, 38-51. [CrossRef] [PubMed]

259. Qin, J.; Zhang, Y.; Hu, L.; Ma, Y.; Gao, J. Cytotoxic metabolites produced by Alternaria No.28, an endophytic fungus isolated from Ginkgo biloba. Nat. Prod. Commun. 2009, 4, 1473-1476. [CrossRef]

260. Lebrun, M.H.; Nicolas, L.; Boutar, M.; Gaudemer, F.; Ranomenjanahary, S.; Gaudemer, A. Relationship between the structure and the phytotoxicity of the fungal toxin tenuazonic acid. Phytochemistry 1988, 27, 77-84. [CrossRef]

261. Wong, C.; Lam, H.; Song, T.; Chen, G.; Li, X. Synthesis of constrained head-to-tail cyclic tetrapeptides by an imine-induced ring-closing/contraction strategy. Angew. Chem. Int. Ed. 2013, 52, 10212-10215. [CrossRef] [PubMed]

262. Meyer, W.L.; Kuyper, L.F.; Phelps, D.W.; Cordes, A.W. Structure of the cyclic tetrapeptide tentoxin. Crystal and molecular structure of the dihydro derivative. J. Chem. Soc. Chem. Commun. 1974, 184, 339-340. [CrossRef]

263. Liu, Y.; Rychlik, M. Development of a stable isotope dilution LC-MS/MS method for the Alternaria toxins tentoxin, dihydrotentoxin, and isotentoxin. J. Agric. Food Chem. 2013, 61, 2970-2978. [CrossRef]

264. Rodríguez-Carrasco, Y.; Mañes, J.; Berrada, H.; Juan, C. Development and validation of a LC-ESI-MS/MS method for the determination of Alternaria toxins alternariol, alternariol methyl-ether and tentoxin in tomato and tomato-based products. Toxins 2016, 8, 328. [CrossRef]

265. De Sa, S.V.M.; Monteiro, C.; Fernandes, J.O.; Pinto, E.; Faria, M.A.; Cunha, S.C. Emerging mycotoxins in infant and children foods: A review. Crit. Rev. Food Sci. Nutr. 2021, 1-15. [CrossRef]

266. Halloin, J.M.; Hagedorn, D.J. Effects of tentoxin on enzymic activities in cucumber and cabbage cotyledons. Mycopathologia 1975, 55, 159-162. [CrossRef]

267. Schadler, D.L.; Steele, J.A.; Durbin, R.D. Some effects of tentoxin on mature and developing chloroplasts. Mycopathologia 1976, 58, 101-105. [CrossRef] [PubMed]

268. Steele, J.A.; Uchytil, T.F.; Durbin, R.D.; Bhatnagar, P.; Rich, D.H. Chloroplast coupling factor 1: A species-specific receptor for tentoxin. Proc. Natl. Acad. Sci. USA 1976, 73, 2245-2248. [CrossRef] [PubMed]

269. Groth, G. Structure of spinach chloroplast F-1-ATPase complexed with the phytopathogenic inhibitor tentoxin. Proc. Natl. Acad. Sci. USA 2002, 99, 3464-3468. [CrossRef] [PubMed]

270. Santolini, J.; Haraux, F.; Sigalat, C.; Moal, G.; Andre, F. Kinetic analysis of tentoxin binding to chloroplast F-1-ATPase-A model for the overactivation process. J. Biol. Chem. 1999, 274, 849-858. [CrossRef] [PubMed]

271. Yang, J.; Williams, D.; Kandiah, E.; Fromme, P.; Chiu, P.L. Structural basis of redox modulation on chloroplast ATP synthase. Commun. Biol. 2020, 3, 842. [CrossRef] [PubMed] 
272. Klotz, M.G. The action of tentoxin on membrane processes in plants. Physiol. Plantarum 1988, 74, 575-582. [CrossRef]

273. Ramm, K.; Ramm, M.; Liebermann, B.; Reuter, G. Studies of the biosynthesis of tentoxin by AIternaria alternata. Microbiology 1994, 140, 3257-3266. [CrossRef]

274. Liebermann, B.; Ramm, K. N-methylation in the biosynthesis of the phytotoxin tentoxin. Phytochemistry 1991, 30, 1815-1817. [CrossRef]

275. De Bruyne, L.; Van Poucke, C.; Di Mavungu, D.J.; Zainudin, N.A.I.M.; Vanhaecke, L.; De Vleesschauwer, D.; Turgeon, B.G.; De Saeger, S.; Hofte, M. Comparative chemical screening and genetic analysis reveal tentoxin as a new virulence factor in Cochliobolus miyabeanus, the causal agent of brown spot disease on rice. Mol. Plant Pathol. 2016, 17, 805-817. [CrossRef]

276. Li, Y.; Han, W.; Gui, X.; Wei, T.; Tang, S.; Jin, J. Putative nonribosomal peptide synthetase and cytochrome P450 genes responsible for tentoxin biosynthesis in Alternaria alternata ZJ33. Toxins 2016, 8, 234. [CrossRef] [PubMed]

277. Rutten, T.L.M.; Knuiman, B. Brefeldin A effects on tobacco pollen tubes. Eur. J. Cell Biol. 1993, 61, 247-255.

278. Driouich, A.; Jauneau, A.; Staehelin, L.A. 7-Dehydrobrefeldin A, a naturally occurring brefeldin A derivative, inhibits secretion and causes a cis-to-trans breakdown of Golgi stacks in plant cells. Plant Physiol. 1997, 113, 487-492. [CrossRef] [PubMed]

279. Harri, E.; LoeMer, W.; Singh, H.; Stahlin, H.; Tamm, C. Die constitution von brefeldin A. Helv. Chem. Acta 1963, 46, 1235-1243.

280. Wang, J.; Huang, Y.; Fang, M.; Zhang, Y.; Zheng, Z.; Zhao, Y.; Su, W. Brefeldin A, a cytotoxin produced by Paecilomyces sp. and Aspergillus clavatus isolated from Taxus mairei and Torreya grandis. FEMS Immunol. Med. Microbiol. 2002, 34, 51-57. [CrossRef] [PubMed]

281. Misumi, Y.; Miki, K.; Takatsuki, A.; Tamura, G.; Ikehara, Y. Novel blockade by brefeldin A of intracellular transport of secretory proteins in cultured rat hepatocytes. J. Biol. Chem. 1986, 261, 1398-1403. [CrossRef]

282. Fujiwara, T.; Oda, K.; Yokota, S.; Takatsuki, A.; Ikehara, Y. Brefeldin A causes disassembly of the golgi-complex and accumulation of secretory proteins in the endoplasmic reticulum. J. Biol. Chem. 1986, 263, 18545-18552. [CrossRef]

283. Gamboa-Angulo, M.M.; Escalante-Erosa, F.; García-Sosa, K.; Alejos-González, F.; Delgado-Lamas, G.; Peña-Podríguez, L.M. Natural zinniol derivatives from Alternaria tagetica. Isolation, synthesis, and structure-activity correlation. J. Agric. Food Chem. 2002, 50, 1053-1058. [CrossRef] [PubMed]

284. Berestetskii, A.O.; Yuzikhin, O.S.; Katkova, A.S.; Dobrodumov, A.V.; Sivogrivov, D.E.; Kolombet, L.V. Isolation, identification, and characteristics of the phytotoxin produced by the fungus Alternaria cirsinoxia. Appl. Biochem. Microbiol. 2010, 46, 75-79. [CrossRef]

285. Thuleau, P.; Graziana, A.; Rossignol, M.; Kauss, H.; Auriol, P.; Ranjeva, R. Binding of the phytotoxin zinniol stimulates the entry of calcium into plant protoplasts. Proc. Natl. Acad. Sci. USA 1988, 85, 5932-5935. [CrossRef]

286. Lecomte, M.; Hamama, L.; Voisine, L.; Gatto, J.; He’lesbeux, J.-J.; Séraphin, D.; Peña-Rodriguez, L.M.; Richomme, P.; Boedo, C.; Yovanopoulos, C.; et al. Partial resistance of carrot to Alternaria dauci correlates with in vitro cultured carrot cell resistance to fungal exudates. PLoS ONE 2014, 9, e101008. [CrossRef] [PubMed]

287. Qui, J.A.; Castro-Concha, L.A.; García-Sosa, K.; Miranda-Ham, M.L.; Peña-Rodríguez, L.M. Is zinniol a true phytotoxin? Evaluation of its activity at the cellular level against Tagetes erecta. J. Gen. Plant Pathol. 2010, 76, 94-101. [CrossRef]

288. Nukina, M.; Marumo, S. $\alpha$-Acetylorcinol from Cochliobolus lunata. Agric. Biol. Chem. 1977, 41, 717. [CrossRef]

289. Venkatasubbaiah, P.; Baudoin, A.B.A.M.; Chilton, W.S. Leaf spot of hemp dogbane caused by Stagonospora apocyni, and its phytotoxins. J. Phytopathol. 1992, 135, 309-316. [CrossRef]

290. Peng, W.; You, F.; Li, X.L.; Jia, M.; Zheng, C.; Han, T.; Qin, L.P. A new diphenyl ether from the endophytic fungus Verticillium sp. isolated from Rehmannia glutinosa. Chin. J. Nat. Med. 2013, 11, 673-675. [CrossRef] [PubMed]

291. Andolfi, A.; Boari, A.; Evidente, M.; Cimmino, A.; Vurro, M.; Ash, G.; Evidente, A. Gulypyrones A and B and phomentrioloxins B and $\mathrm{C}$ produced by diaporthe gulyae, a potential mycoherbicide for Saffron Thistle (Carthamus lanatus). J. Nat. Prod. 2015, 78, 623-629. [CrossRef] [PubMed]

292. Chaves, N.; Sosa, T.; Al, J.C.; Escudero, J.C. Identification and effects of interaction phytotoxic compounds from exudade of Cistus ladanifer leaves. J. Chem. Ecol. 2001, 27, 611-621. [CrossRef] [PubMed]

293. Cho, J.Y.; Moon, J.H.; Seong, K.Y.; Park, K.H. Antimicrobial activity of 4-hydroxybenzoic acid and trans 4-hydroxycinnamic acid isolated and identified from rice hull. Biosci. Biotechnol. Biochem. 1998, 62, 2273-2276. [CrossRef]

294. Merkl, R.; Hrádková, I.; Filip, V.; Šmidrkal, J. Antimicrobial and antioxidant properties of phenolic acids alkyl esters. Czech J. Food Sci. 2010, 28, 275-279. [CrossRef]

295. Deba, F.; Xuan, T.D.; Yasuda, M.; Tawata, S. Herbicidal and fungicidal activities and identification of potential phytotoxins from Bidens pilosa L. var. radiata Scherff. Weed Biol. Manag. 2007, 7, 77-83. [CrossRef]

296. Zuo, S.; Zhou, S.; Ye, L.; Ma, S. Synergistic and antagonistic interactions among five allelochemicals with antialgal effects on bloom-forming Microcystis aeruginosa. Ecol. Eng. 2016, 97, 486-492. [CrossRef]

297. Ceylan, O.; Alic, H. Antibiofilm, antioxidant, antimutagenic activities and phenolic compounds of Allium orientale BOISS. Brazilian Arch. Biol. Technol. 2015, 58, 935-943. [CrossRef]

298. Pugazhendhi, D.; Pope, G.S.; Darbre, P.D. Oestrogenic activity of $p$-hydroxybenzoic acid (common metabolite of paraben esters) and methylparaben in human breast cancer cell lines. J. Appl. Toxicol. 2005, 25, 301-309. [CrossRef] [PubMed] 